Kotzé, "Comments on the Expression," OTE 28/1 (2015): 121-153

\title{
Comments on the Expression of Hope in LXX Lamentations 5:19-22
}

\author{
GIDEON R. KOTZÉ (STELLENBOSCH UNIVERSITY)
}

\begin{abstract}
In the writings of the $H B$, hope appears to be an attitude in which human beings look forward and wait in expectation for the advent or arrival of what is considered to be future possibilities. This often involves a measure of uncertainty and/or tension between the present situation and the state or conditions that are hoped for. Furthermore, the acts and words of YHWH have a central place in the worldview in which the hopes are grounded. Lamentations 5:19-22 is an interesting example of such an attitude of hope in the HB. The Hebrew wording (as represented by the MT) is, however, not the only legitimate representative of the content of these verses. The Greek translation (LXX Lam) is another important witness to the text and content of Lam 5:19-22. The purpose of this study is to determine how LXX Lam presents the hope that is expressed in these verses and thereby to gain a better understanding of it as a representative of the content of Lamentations.
\end{abstract}

Key concepts: hope, Septuagint (LXX), Lamentations, textual representative, ancient translation.

\section{A INTRODUCTION}

In the writings of the $\mathrm{HB}$, hope is expressed in multiple ways and in a variety of literary contexts. ${ }^{1}$ Biblical Hebrew does not have a clearly fixed terminology for hope. A number of verbs and their nominal derivatives have connotations of hope as part of their semantic potential. ${ }^{2}$ These words include (to wait for"), תקוה ("hope"), מקוה ("hope"), תוחלת ("hope"), חכה ("to wait"), wait"/"to await"), שבר ("to hope"/"to wait"; noun: "hope"), and ("אפרה ("look

* Article submitted: 18/06/2014; accepted: 29/01/2015. To cite: Gideon R. Kotzé, "Comments on the Expression of Hope in LXX Lamentations 5:19-22," OTE 28/1 (2015): 121-153, DOI: http://dx.doi.org/10.17159/2312-3621/2015/v28n1a9

1 For discussions on hope in the HB, see Rolf P. Knierim, "Hope in the Old Testament," in The Task of Old Testament Theology: Substance, Method and Cases (ed. Rolf P. Knierim; Grand Rapids: Eerdmans, 1995), 244-268; Walther Zimmerli, Man and his Hope in the Old Testament (London: SCM Press, 1971); Claus Westermann, "Das Hoffen im Alten Testament: Eine Begriffsuntersuchung," in Forschung am alten Testament: Gesammelte Studien (ed. Claus Westermann; München: Chr. Kaiser Verlag, 1964), 219-265.

2 Cf. Knierim, "Hope," 246-247; Zimmerli, Man and his Hope, 7-8; Westermann, "Hoffen," 221. 
out"/"keep watch"). ${ }^{3}$ This terminological diversity regarding the concept of hope is matched by the wide range of literary genres in which the writings of the HB communicate hope. Hope in the HB finds expression in narratives, wisdom sayings, prophetic oracles, apocalypses and cultic poetry, such as hymns and (communal and individual) laments, to name but a few well-known examples. According to Knierim, ${ }^{4}$ the different words and the multitude of literary forms reveal the basic structure of hope in the HB. Hope is an attitude in which human beings look forward and wait in expectation for the advent or arrival of what is considered to be future possibilities. To a certain extent, hope presupposes "an uncertainty or a tension between the present state and the state hoped for, between the known present and the unknown future, and between the state of desire and the state of satisfaction." Knierim argues that this attitude of hope in the HB is made possible by a, so-called, dynamistic worldview "which allows for or even generates projection into future on the basis of past experience." "For the people whose hopes are articulated in the writings of the HB the acts and words of YHWH have a central place in the worldview in which the hopes are grounded. As a result, hope in the HB is, in the words of Westermann, "im eigentlichen Sinn Hoffen auf Jahweh."7

These various aspects of hope in the HB, the variety of words used to express it, the attitude of looking forward/waiting in expectation, the presupposed tension between the present and anticipated future and its basis in a "YHWHcentred" worldview, are illustrated well in a passage from the individual lament genre, Lam 3:16-33. This passage, especially vv. 19-33, is one of the featured texts in scholars' investigations of hope in the HB and the book of Lamentations

3 Knierim, "Hope," 246-247, also refers to the verbs בטח ("to feel safe"/"to trust"), דמם ("to be, keep, or stand still"), נבט ("to look upon, behold [expectantly]"), כתר ("to have patience with"), דמהה ("to seek refuge"), דרש ("to seek"/"to inquire"), דמה ("to be still/“to be silent"), שאל ("to ask for"/"to inquire of") and בקר ("to attend to"),

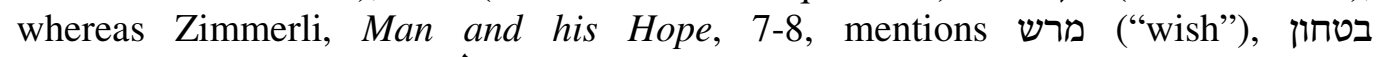
("confidence"/“trust") and כסלה ("confidence"). Wordlists of this kind contribute little to a better understanding of the conception of hope in the HB writings. In order to arrive at such a better understanding, it is necessary, first, to study the words as they are used in the syntactic and literary contexts of specific passages. Cf., in this regard, James Barr, The Semantics of Biblical Language (Oxford: Oxford University Press, 1961), 269. Secondly, it is important to determine how the words' connotation of hope relates to their other possible meanings. Thirdly, the meanings of the words are connected to the culture, worldviews and experiences of the people who use them. It is, therefore, imperative to study the Hebrew words that can express hope against the background of ANE perceptions of the world, especially in the southern Levant.

4 Knierim, "Hope," 251.

5 Knierim, "Hope," 248.

6 Knierim, "Hope," 253.

7 Westermann, "Hoffen," 220. 
in particular. ${ }^{8}$ Dobbs-Allsopp notes that Lam 3:19-33 is the "lone thematic discussion" of hope in Lamentations, ${ }^{9}$ but it is not the only passage in the five poems where hope is expressed. The final four verses of the fifth poem, Lam 5:19-22, is another good example of hope in Lamentations:

${ }^{19}$ (But) you, O YHWH, are sitting enthroned forever;

Your throne is for generation and generation.

${ }^{20}$ Why do you forget us enduringly?

(Why) do you abandon us for length of days?

${ }^{21}$ Turn us back to yourself, O YHWH, so that we may come back;

Renew our days as in ancient / former times.

${ }^{22}$ Even though / but instead / unless you have completely / truly

rejected us,

you are exceedingly angry with us. ${ }^{10}$

Although the Biblical Hebrew words for hope do not appear in these four verses, the words of the first-person plural speakers manifest an attitude of desire or expectation regarding the future which is orientated towards the past (v. 21). This hope is directed at YHWH (vv. 19 and 21) and there is a clear tension between the present situation and the hoped for future (vv. 20 and 22). ${ }^{11}$ These comments on the hope in Lam 5:19-22 are based on the translation of the Hebrew wording of these verses in the MT, as it is represented by one particular manuscript, Codex Leningradensis. ${ }^{12}$ As the only textual witness in which the Hebrew wording of Lam 5:19-22 is completely preserved, the MT is an

$8 \quad$ On hope in Lamentations, especially Lam 3, see, e.g., Heath A. Thomas, "“I Will Hope in Him': Theology and Hope in Lamentations," in A God of Faithfulness: Essays in Honour of J. Gordon McConville on His 60th Birthday (ed. Jamie A. Grant, Alison Lo, and Gordon Wenham; New York: Bloomsbury, 2011), 203-221; Jože Krašovec, "The Source of Hope in the Book of Lamentations," VT 42/2 (1992): 223233; Johan Renkema, "Misschien is er Hoop..." De Theologische Vooronderstellingen van het Boek Klaagliederen (Kampen: Wever, 1983), 297-301.

9 Frederick W. Dobbs-Allsopp, Lamentations (IBC; Louisville: John Knox Press, 2002), 48.

10 The translation is my own.

11 Knierim, "Hope," 259-260, discusses Lam 5:19-22 as an example of hope in the HB that stands in tension with reality. For another perspective on the hope expressed in these verses, see Heath A. Thomas, Poetry and Theology in the Book of Lamentations: The Aesthetics of an Open Text (Sheffield: Sheffield Phoenix Press, 2013), 233236.

12 This eleventh century manuscript forms the base text of the Biblia Hebraica Quinta (BHQ) and Biblia Hebraica Stuttgartensia (BHS) critical editions that are used for the purposes of this study: Rolf Schäfer, "Lamentations," in Biblia Hebraica quinta editione cum apparatu critico novis curis elaborato: General Introduction and Megilloth (ed. Adrian Schenker, et al.; Stuttgart: Deutsche Bibelgesellschaft, 2004), 54-72, 113*-136*; Theodore H. Robinson, "Threni," in Biblia Hebraica Stuttgartensia (ed. Karl Elliger and Wilhelm Rudolph; Stuttgart: Deutsche Bibelgesellschaft, 1977), 1354-1367. 
important representative of this passage's content. Nevertheless, the MT is not the only textual representative of Lamentations and, therefore, not the only legitimate witness to its content. The ancient translations are also important witnesses to the content of Lamentations, including the hope that is articulated in a passage such as Lam 5:19-22. ${ }^{13}$ This study intends to determine how the Greek translation of Lamentations presents the hope that is expressed in Lam 5:19-22. Instead of examining the readings in LXX Lam only in cases where there is a possibility that the Greek translation is based on a Hebrew reading that differs from and has the potential of being more original than the reading in the MT, this study examines LXX Lam as both a translation of a Hebrew Vorlage and as a witness to the content of Lamentations. It aims to gain a better understanding of LXX Lam as such a witness by studying the way in which the Greek translation presents the expression of hope in Lam 5:19-22.

\section{B INTERPRETING LXX LAM}

A study of how the LXX text presents the hope that is expressed in Lam 5:19-22 entails a detailed comparative analysis of the wording of the translation. It is only through an analysis of the wording of the translation that one can explain differences between the Greek and Hebrew texts, construe the probable meaning of the Greek version of a passage and draw conclusions regarding the intentions that the translator might have had with his specific renderings. ${ }^{14}$ Such an analysis must take three aspects of the Greek wording into consideration: (1) the shape of the original translation in distinction from later changes during its transmission; (2) the translation technique exhibited by the translated text; and (3) the textual character of the Hebrew Vorlage on which the original translation was based.

The first important factor in the study of LXX Lam's presentation of hope in Lam 5:19-22 is that the analysis must be based on the Old Greek text. The term "Old Greek" refers to the particular wording of a translation that scholars consider the most likely to be the original text. The Old Greek text, or original Greek translation of Lamentations, must therefore be distinguished from readings that were created during its transmission history. These readings include deliberate revisions and changes to the wording of the original translation, as well as accidental scribal errors. Although such inner-Greek develop-

13 Two of the four Qumran manuscripts of Lamentations, 4QLam and 5QLam ${ }^{\mathrm{a}}$, are also important textual witnesses, but the final four verses of Lam 5 were, unfortunately, not preserved in any of these manuscripts. The other two manuscripts, 3QLam and $5 \mathrm{QLam}{ }^{\mathrm{b}}$, are extremely fragmentary and cannot be used in any discussion on the content of passages.

14 Cf. Anneli Aejmelaeus, "Translation Technique and the Intention of the Translator," in VII Congress of the International Organization for Septuagint and Cognate Studies, Leuven 1989 (SBLSCS 31; ed. Claude E. Cox; Atlanta: Scholars Press, 1991), 30. 
ments often make for interesting reading, the analysis of this study is primarily concerned with the work of the original translator of Lamentations and the wording of the Old Greek text of LXX Lam. ${ }^{15}$

The decision to focus on the original text of LXX Lam means that an examination of the translation technique must form a central part of the analysis of this translation's wording. Translation technique is a "collective name for all the different renderings used by the translator. Study of translation technique aims at describing what the result of the work of the translator turned out to be like." Lamentations as a "literal" translation in which the translator often rendered his Hebrew Vorlage word for word. ${ }^{17}$ LXX Lam is also an acknowledged member of the kaige group of translations and revisions. ${ }^{18}$ The fact that LXX Lam exhibits some of the characteristic traits of the kaige group underscores the literal nature of the Greek text's translation profile. ${ }^{19}$ Such general characterisations of LXX Lam's translation technique might be helpful in the analysis. They can also be misleading, if they form the sole basis for an explanation of a particular reading. In the study of the wording of LXX Lam, each passage must be analysed in detail and the most probable explanations of how the readings might have been created during the translation process must be considered.

15 For the purposes of the analysis, I make use of the critical Göttingen edition prepared by Joseph Ziegler, Septuaginta: Vetus Testamentum Graecum XV: Jeremias, Baruch, Threni, Epistula Jeremiae (3rd ed; Göttingen: Vandenhoeck \& Ruprecht, 2006). The edition of Ralhfs that was recently edited by Robert Hanhart is also consulted: Alfred Rahlfs, Septuaginta: Id est Vetus Testamentum graece iuxta LXX interpretes (ed. Robert Hanhart; Stuttgart: Deutsche Bibelgesellschaft, 2006). On the textual history of LXX Lam, see Frank Ueberschaer, "Die Septuaginta der Klagelieder: Überlegungen zu Entstehung und Textgeschichte," in Die Septuaginta: Entstehung, Sprache, Geschichte (ed. Siegfried Kreuzer, Martin Meiser, and Marcus Sigismund; WUNT 286; Tübingen: Mohr Siebeck, 2012), 98-111.

16 Aejmelaeus, "Translation Technique," 27. Cf. also Anneli Aejmelaeus, "What We Talk About When We Talk about Translation Technique," in X Congress of the International Organization for Septuagint and Cognate Studies, Oslo, 1998 (ed. Bernard A. Taylor; SBLSCS 51; Atlanta: Society of Biblical Literature, 2001), 531-552.

17 Cf. Rainer Hirsch-Luipold and Christl M. Maier, "Threnoi/Threni Seu Lamentationes/Die Klagelieder," in Psalmen bis Daniel (vol. 2 of Septuaginta Deutsch: Erläuterungen und Kommentare zum griechischen Alten Testament; ed. Martin Karrer and Wolfgang Kraus; Stuttgart: Deutsche Bibelgesellschaft, 2011), 2829-2830.

18 See Dominique Barthélemy, Les Devanciers d'Aquila (VTSup 10; Leiden: Brill, 1963), 158-160; and Isabelle Assan-Dhôte and Jacqueline Moatti-Fine, Baruch, Lamentations, Lettre de Jérémie (BdA 25.2; Paris: Cerf, 2005), 155-157.

19 Cf. Peter J. Gentry, "Lamentations," in A New English Translation of the Septuagint (ed. Albert Pietersma and Benjamin G. Wright; Oxford: Oxford University Press, 2007), 934. 
Finally, with regard to the textual character of the Hebrew Vorlage of LXX Lam, Albrektson concludes, after an extensive text-critical analysis, that the Greek translation was based on a Hebrew text that was almost identical to the consonantal base of the MT. ${ }^{20}$ This is an important conclusion, but it does not rule out the possibility that in some instances a variant reading in the Greek translation's Hebrew parent text is responsible for a difference in wordings between LXX Lam and the MT. At the same time, the fact that the Hebrew Vorlage of LXX Lam was probably very similar to the consonantal base of the MT implies that many of the differences between the Greek and Hebrew texts of Lamentations can most likely be attributed to the translator's interpretation of his Hebrew text.

In what follows, the original text of LXX Lam 5:19-22 will be analysed in order to establish how the wording of the Greek translation presents the hope that is expressed in the Hebrew text. The analyses will compare the Greek translation with the extant Hebrew texts, investigate the nature of the translation of the individual verses and, in cases where there are differences between the Greek and the Hebrew texts, determine the most plausible explanations for the differences in wording. The analyses will conclude with comments on the Greek translation's presentation of the hope that is articulated in Lam 5:19-22. These concluding comments will be based on the results of the comparative analyses of the four verses.

\section{ANALYSES OF LXX LAM 5:19-22 21}

\section{$1 \quad$ Lamentations 5:19}

\section{MT}

אתה יהוה לעולם תשב כסאך לדר ודור

(But) you, O Yнwh, are sitting (enthroned) forever;

Your throne is for generation and generation.

20 Cf. Bertil Albrektson, Studies in the Text and Theology of the Book of Lamentations with a Critical Edition of the Peshitta Text (Lund: CWK Gleerup, 1963), 210.

21 The analyses of the four verses make reference to a poet, translator and speakers / speaking voice. The poet refers to the people who were responsible for the composition of Lam 5 in writing. Insofar as the MT cannot simply be equated with the poem's original text, the poet does not necessarily refer to the original author. For the purposes of the analyses in which the MT is used for comparison with the LXX, "the poet" is a collective name for the scribes who contributed to the wording of the poem as it is represented by the MT (and more specifically, Codex Leningradensis). Whereas the MT is not the original Hebrew text of Lam 5, the Göttingen edition's eclectic text of the Greek translation which was established by scholars can, provisionally, claim the status of original text for LXX Lam. The translator then refers to the scribe who made the translation from a Hebrew Vorlage that was not identical to the MT. Although we 


\section{LXX}

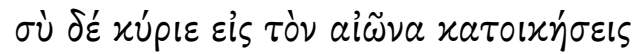

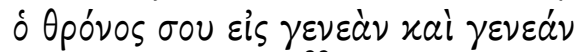

But you, O Lord, ${ }^{22}$ you will dwell forever;

Your throne is for generation and generation.

Lamentations 5:19 in the MT consist of two semantically parallel cola. The two prepositional phrases לעולם and לדר ודור correspond with one another and indicate undetermined duration of time. ${ }^{23}$ The verb תשבד is parallel to the noun כסאך and this implies that the verbal root ישב probably has the meaning "to sit enthroned" / "to reign" in the context of this verse. ${ }^{24}$ As a yiqtol, תשב has a present temporal reference here and expresses continuative action. The verb is marked for person (second-person masculine singular) and, therefore, the use of the independent personal pronoun אתה seems superfluous. Nevertheless, its presence and fronting (its position in the preverbal field of the clause) fulfil an important semantic-pragmatic function. The pronoun does not only signal the switch from a description of Mount Zion's desolation in v. 18 to an address to YHWH in v. 19, but also reactivates YHWH as the topic of the utterance. ${ }^{25}$ The reactivation serves to contrast YHWH on his everlasting throne with the topic of the previous clause, Mount Zion, which is said to have been deserted and to have become the haunt of foxes. As the mountain of God and the site of Solomon's temple in Jerusalem, Mount Zion was considered to be the earthly abode of YHWH and the location of his throne in Israelite religious

primarily have access to the intentions of the poet and translator through the clues provided by the wordings of the Hebrew and Greek texts, this does not mean that the speakers in the texts can simply be identified with either the poet or the translator. The first-person speaking voice in Lam 5 is a part of the poem and translation as literary creations. It therefore does not necessarily belong to a specific, identifiable historical community.

22 On the translation of the tetragrammaton with xúplos in LXX translations of HB writings, see, e.g., Martin Rösel, "Theo-logie der griechischen Bibel: Zur Wiedergabe der Gottesaussagen im LXX-Pentateuch," VT 48/1 (1998): 49-62; and Albert Pietersma, "Kyrios or Tetragram: A Renewed Quest for the Original Septuagint," in De Septuaginta: Studies in Honour of John William Wevers on his Sixty-Fifth Birthday (ed. Albert Pietersma and Claude Cox; Mississauga: Benben Publications, 1984), 85102.

23 Cf. Ernst Jenni, "Das Wort 'ōlām im Alten Testament," ZAW 64 (1952): 237; and James Barr, Biblical Words for Time (rev. ed.; SBT 33; London: SCM Press, 1969), 73, 123-124.

24 The words of the bicolon, excluding the superfluous personal pronoun and the

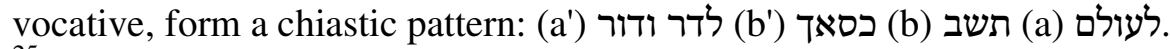

25 Before v. 19, YHWH is the topic of an utterance only in v. 1. Like v. 19, YHWH is also an addressee in this opening verse of Lam 5. 
traditions that are reflected in certain writings of the $\mathrm{HB}^{26}$ With its references to the roaming foxes on desolate Mount Zion, Lam 5:18 implies that the temple has been destroyed and creates the impression that chaos has infiltrated YHWH's abandoned earthly residence. ${ }^{27}$ The invasion of chaos into culture forms part of the well-known topos of a world turned upside down (mundus inversus) in ANE literature. ${ }^{28}$ The image of desert-dwelling wild animals, which represent the chaotic, anti-human world, ${ }^{29}$ becoming the new occupants of ruined sites that once embodied the pinnacle of culture, communicates the

26 Concerning Mount Zion as the dwelling place of YHWH and the location of his throne (represented by the two cherubs in the temple's $d^{e} b \hat{\imath} r$ ), see, e.g., the comments of Victor A. Hurowitz, "YHWH's Exalted House - Aspects of the Design and Symbolism of Solomon's Temple," in Temple and Worship in Biblical Israel (ed. John Day; London: T. \& T. Clark, 2007), 86, 96-97; and Christian Frevel, "Zerbrochene Zier: Tempel und Tempelzerstörung in den Klageliedern (Threni)," in Gottestadt und Gottesgarten: $\mathrm{Zu}$ Geschichte und Theologie des Jerusalemer Tempels (ed. Othmar Keel and Erich Zenger; QD 191; Freiburg: Herder, 2002), 105-106, 140.

27 With regard to שועלים (translated here as "foxes") as representatives of chaos, see Frevel, "Zerbrochene Zier," 140. Foxes and jackals count among the wild animals that are associated with ruined cities in ANE literature. They therefore symbolise desolation, according to Oded Borowski, "Animals in the Literature of Syria-Palestine," in $A$ History of the Animal World in the Ancient Near East (ed. Billie Jean Collins; HdO 64; Leiden: Brill, 2002), 298. For examples of this theme in Mesopotamian city and balag laments, other ANE texts and the prophetic writings in the HB, see Frederick W. Dobbs-Allsopp, Weep, O Daughter of Zion: A Study of the City-Lament Genre in the Hebrew Bible (BibOr 44; Rome: Pontifical Biblical Institute, 1993), 66-67; and Delbert R. Hillers, Treaty-Curses and the Old Testament Prophets (BibOr 16; Rome: Pontifical Biblical Institute, 1964), 44-45, 53. On foxes and Lam 5:18 as the dramatic climax of the lament, see Antje Labahn, "Wild Animals and Chasing Shadows: Animal Metaphors in Lamentations as Indicators for Individual Threat," in Metaphor in the Hebrew Bible (ed. Pierre van Hecke; Leuven: Peeters, 2005), 82-84.

28 Kruger demonstrates that this topos is an important notion in ANE descriptions of disaster. See, Paul A. Kruger, "Disaster and the Topos of the World Upside Down: Selected Cases from the Ancient Near Eastern World," in Disaster and Relief Management: Katastrophen und ihre Bewältigung (ed. Angelika Berlejung; FAT 81; Tübingen: Mohr Siebeck, 2012), 391-424.

29 Cf. Peter Riede, “'Ich bin ein Bruder der Schakale' (Hi 30, 29): Tiere als Exponenten der gegenmenschlichen Welt in der Bildsprache der Hiobdialoge," in Im Spiegel der Tiere: Studien zum Verhältnis von Mensch und Tier im alten Israel (ed. Peter Riede; OBO 187; Freiburg: Universitätsverlag / Göttingen: Vandenhoeck \& Ruptrecht, 2002), 120-122; Bernd Janowski and Ute Neumann-Gorsolke, "Das Tier als Exponent dämonischer Mächte," in Gefährten und Feinde des Menschen: Das Tier in der Lebenswelt des alten Israel (ed. Bernd Janowksi, Ute Neumann-Gorsolke, and Uwe Gleßmer; Neukirchen-Vluyn: Neukirchener Verlag, 1993), 278-282; Othmar Keel, Die Welt der altorientalischen Bildsymbolik und das Alte Testament: Am Beispiel der Psalmen (3rd ed.; Zürich: Benziger Verlag / Neukirchener-Vluyn: Neukirchener Verlag, 1980), 66. 
inversion of normal conditions well. In Lam 5:18, the poet uses this established image to describe the disaster of the desolate divine dwelling place. ${ }^{30}$ According to the next verse (Lam 5:19), however, YHWH's royal power and authority remain unaffected by this. The desolation of Mount Zion does not mean that YHWH has abdication his throne. Despite the destruction of the temple, the place on earth where God's throne was located, and the desolation of God's mountain, v. 19 shows that the religious worldview that underlies Lam 5 allowed the poet to still think of YHWH in terms of royal imagery. ${ }^{31}$ The verse claims that YHWH sits forever in a position of sovereign power and, therefore, possesses the ability to do something about the suffering of the community.

In the Greek translation, the contrast between the observations in v. 18 and the confession in v. 19 is explicitly marked by the conjunction $\delta \varepsilon^{\prime}$. This conjunction is a plus in the text of the Greek translation when compared to the wording of Codex Leningradensis. Other Masoretic manuscripts contain the reading ואתה, which was probably also in the Hebrew text that was used in the translation process. The counterparts of $\sigma \dot{v} \delta \varepsilon^{\prime}$ in the Peshitta and the Vulgate, גu a and tu autem, also presuppose the reading ואתה. This might very well be the original Hebrew reading, as suggested by some scholars. ${ }^{32}$ Apart from the plus, the wording of the Greek translation agrees with the word order of the MT. Like the MT, only the first of the two clauses in the Old Greek text contains a

30 Kruger, "Disaster," 412-413.

31 It is not stated explicitly in v. 19 that YHWH is sitting enthroned in heaven. It might nevertheless be implied. Frevel, "Zerbrochene Zier," 109, maintains that the idea of YHWH dwelling in heaven did not originate during the "exilic" period, but was already a "pre-exilic" belief. He concedes that the notion of God dwelling in heaven, removed from earth, became more prominent after the exile (Frevel, "Zerbrochene Zier," 120). Although the exact dating of Lam 5 is a matter of scholarly dispute, there is consensus that it was composed after the destruction of Jerusalem by the Babylonians in 587 B.C.E. The contrast between desolate Mount Zion and YHWH's eternal (heavenly) throne expressed in Lam 5:18-19 is rooted in the view that YHWH reigns in heaven and therefore his rule, authority and power remains unaffected by the destruction of the place where the divine king was once thought to be present. It is also interesting to note that in "exilic" and "post-exilic" texts that deal with the heavenly throne of YHWH (cf., e.g., Pss 33:13-19, 102:13-23, 113:4-9; Isa 66:1-3), it is not a symbol of YHWH's inaccessible transcendence; rather, these texts claim that YHWH intervenes on earth in favour of the poor, needy and those who fear him. See, on this topic, Beate Ego, “'Der Herr blickt herab von der Höhe seines Heiligtums': Zur Vorstellung von Gottes himmlischem Thronen in exilisch-nachexilischer Zeit," ZAW 110 (1998): 556569. The fact that a measure of uncertainty clings to the hope that is expressed in MT Lam 5:19-22 means that this passage does not stand in line with "exilic"/"postexilic" texts that speak positively of YHWH looking down from heaven and delivering people who are in need.

32 Cf. Wilhelm Rudolph, "Der Text der Klagelieder," ZAW 56 (1938): 122; and the critical apparatus of BHS. The loss of the initial waw can be attributed to haplography, seeing as the final word of v. 18, ends a waw. 
verb. The second is a nominal clause. Ai $\omega^{\prime} v$ is a standard rendering in the LXX

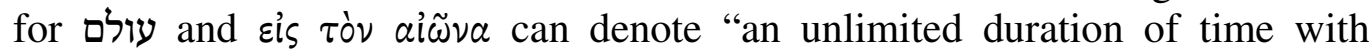
particular focus upon the future."33 Eis $\gamma \varepsilon v \varepsilon a \dot{\nu}$ xai $\gamma \varepsilon \nu \varepsilon a ́ v$, which closely matches לדר ודור, expresses a continuation in successive generations. ${ }^{34}$ This also indicates an undefined duration of time. These data create the impression that the verse was translated quite literally. Nevertheless, the rendering of the

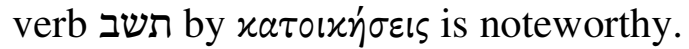

The Greek translator of Lamentations employs two equivalents to translate forms of the Hebrew verbal root ישב. Kati' $\omega$ ("to sit") is used in Lam 1:1,

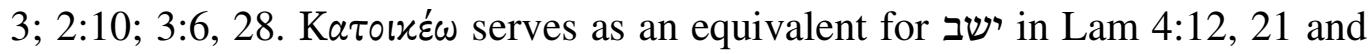
the verse under discussion. The fact that the translator uses different Greek words to render one Hebrew verb means that the translation of תשב with

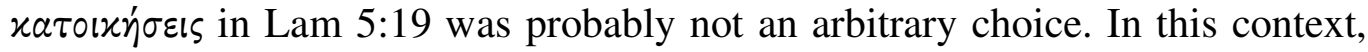

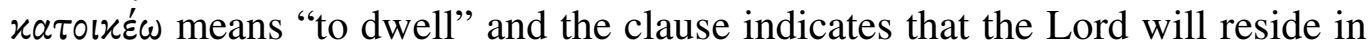
his dwelling place forever. ${ }^{35}$ The sense of the Greek clause therefore differs slightly from the way the first colon in the Hebrew text is usually understood. The meaning of the Greek text is also not quite the same as the Peshitta and Vulgate translations. ${ }^{36}$ Both of these translations stress the eternal existence of

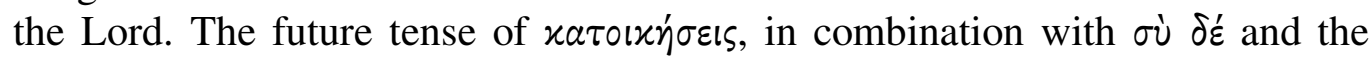

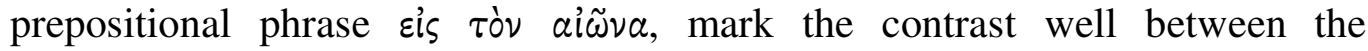
destroyed state of Zion (v. 18) and the Lord who will continue to live on in his dwelling place (v. 19a). The idea that the Lord will dwell forever complements the confession in the second clause that the Lord's throne remains intact for all generations. The focus on the stability and permanence of the Lord's dwelling and kingship in LXX Lam 5:19 ${ }^{37}$ implies that he is not subject to the disaster that has befallen his earthly abode and, thus, that the speakers can still hope in him.

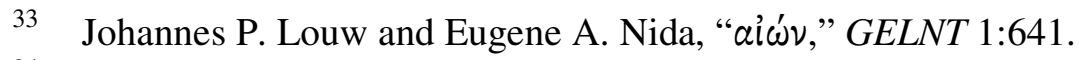

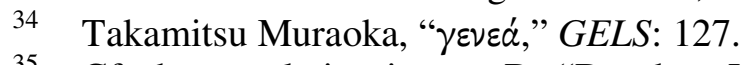

35 Cf. the translation in LXX.D: "Du aber, Herr, wirst in Ewigkeit deine Wohnung haben." Rainer Hirsch-Luipold and Christl M. Maier, "Threnoi/Die Klagelieder," in Septuaginta Deutsch: Das griechische Alte Testament in deutscher Übersetzung (ed. Wolfgang Kraus and Martin Karrer; Stuttgart: Deutsche Bibelgesellschaft, 2009), 1358.

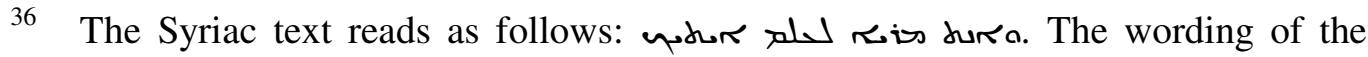
clause in the Vulgate is tu autem Domine in aeternum permanebis. For these quotations, I use the critical editions of Albrektson, Studies in the Text, and Roger Weber, Biblia Sacra iuxta Vulgatam Versionem: Editionem quintam emendatam retractatam praeparavit Roger Gryson (Stuttgart: Deutsche Bibelgesellschaft, 2007).

37 Cf. Assan-Dhôte and Moatti-Fine, Baruch, 283. 


\section{Lamentations 5:20}

MT

למה לנצח תשכחנו תעזבנו לארך ימים

Why do you forget us enduringly?

(Why) do you abandon us for length of days?

\section{LXX}

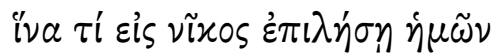

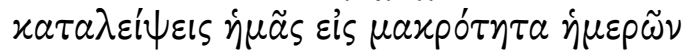

Why will you forget us until victory?

Will you abandon us for length of days?

The two cola of MT Lam 5:20 are not only semantically parallel, but the prepositional phrases and verbs appear to be arranged in a chiastic pattern: prepositional phrase תלנצח (a), תשכחנו (b), תעזבנו (b'), prepositional phrase לארך ימים (a'). The interrogative למה, which is ellipsed in the second colon, introduces questions regarding the reason for the actions expressed by the verbs תעזבנו תשכחנו. The two yiqtol verbs are used here to indicate continuous action, ${ }^{38}$ while the prepositional phrases לארך ימים act as adverbial adjuncts that modify these verbs in terms of unlimited duration of time. Therefore, after confessing in the previous bicolon that it is YHWH who is forever enthroned in power, unaffected by the destruction of Mount Zion, the community now poses the question in this bicolon whether there is a reason why YHWH forgets/abandons them for as long as he is in a position to help them. ${ }^{39}$

The verbs עזב and "to forget" and "to abandon," recall the opening plea of this communal lament in v. 1. The lament begins with the community's invocation of YHWH and the plea that he remember (זכר) what has happened to them and that he must see and take note (הביט וראה) of their disgrace. The long complaint in vv. 2-18 then describes the misery that has befallen the community. The goal of such a description of misery in the lament-genre is to move the deity to have mercy on the community so that he will act on their pleas. ${ }^{40}$ The community's question in v. 20 intimates that, since he is in a position to help them (v. 19), there is no reason why YHWH would continue to forget / abandon the community if, in his mercy, he would just notice and bear in mind (v. 1) what they bring to his attention in their complaint (vv. 2-18).

38 Cf. Robin B. Salters, Lamentations (ICC; London: T. \& T. Clark, 2010), 370.

39 The interrogatives in this verse introduce the theme of divine abandonment and rejection. The poet of Lam 5 returns to this theme in the final verse of the lament. Divine abandonment is a generic feature of Sumerian city laments and Dobbs-Allsopp notes that Lam 5:20 and 5:22 share this staple feature with the Mesopotamian poems. See Dobbs-Allsopp, Weep, 45-51.

40 Cf. Renkema, “Misschien is er Hoop...”, 296. 
The Greek translation resembles the word order and other formal features of the Hebrew text closely. The interrogative iva $\tau$ í reproduces למה, the yiqtol forms of the verbs שכח and are rendered by the future indicatives

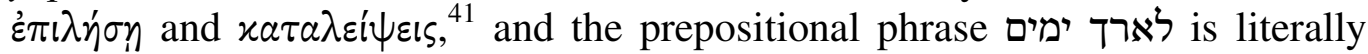

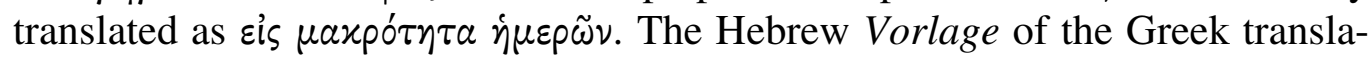
tion seems to have been almost identical to the consonantal base of the MT. The main difference between the Greek and Hebrew wordings of the verse pertains to the prepositional phrase Eis vixos, which serves as the translation of לנצח. The Hebrew adverbial phrase modifies the verb in terms of the duration of an action. According to Anderson, לנצח is always related to the future and does not convey a specified period of time. ${ }^{42}$ In LXX Lam 5:20, eis vixos also has a temporal meaning, but it seems to identify a "victory" as the point in the future

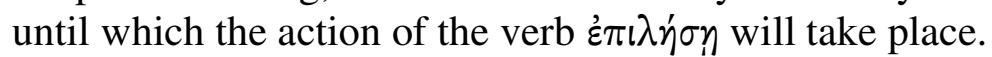

LXX Lam 5:20 is not the only passage in the Greek Jewish scriptures where לנצח is translated by हis vixos. Although the Hebrew phrase is usually

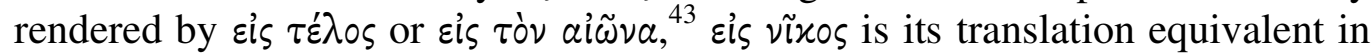
the Old Greek texts of 2 Kdgms 2:26, Jer 3:5, Amos 1:11, 8:7 and Lam 5:20. Furthermore, the noun נצח in Lam 3:18 and 1 Chr 29:11 is rendered by vixos

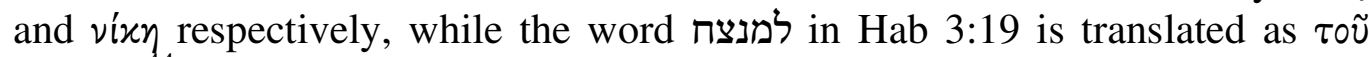
$\nu\left\llcorner x \tilde{\eta} \sigma a l .{ }^{44}\right.$ These data show that forms of vix火os were used in different connections and contexts to translate forms of נצח.

The translation of נצח with עix火s has elicited different explanations from scholars. Kraft ${ }^{45}$ argues that already by Paul's time in the first century C.E. Eis

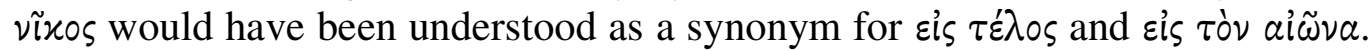
His argument rests on the fact that Eis vixos is used as an equivalent for לנצח in Old Greek texts and that it is hard to imagine that Greek speaking readers would have taken the phrase eis vĩxos to mean "into / until victory" in passages such as 2 Kdgms 2:26, Jer 3:5, Amos 1:11 and 8:7. He therefore suggests that

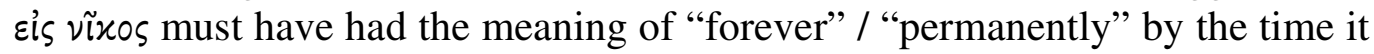

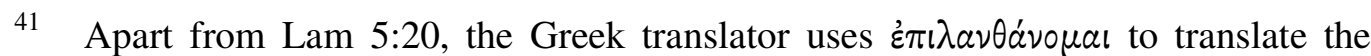

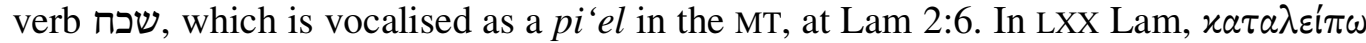
is used only in Lam 5:20 as equivalent for A participle form of this Greek verb appears in LXX Lam 2:22 as translation equivalent for the Hebrew word שריד ("survivor").

42 George W. Anderson, "נֵֶצֶ," ThWAT 5:567.

43 Cf. George B. Caird, "Towards a Lexicon of the Septuagint," in Septuagint Lexicography (ed. Robert A. Kraft; SCS 1; Missoula: Scholars Press, 1975), 136.

44 למנצח appears often in the titles of Psalms. In the original Greek translation, it is rendered with the phrase eis $\tau \dot{0} \tau \varepsilon \dot{\lambda}$ os.

45 Robert A. Kraft, "Eis Nikos = Permanently/Successfully: 1 Cor 15.54, Matt 12.20," in Septuagint Lexicography (ed. Robert A. Kraft; SCS 1; Missoula: Scholars Press, 1975), 153-156. 
was used in 1 Cor 15:54 and Matt 12:20. In contrast to Kraft, Caird ${ }^{46}$ claims that the LXX translators must have intended Eis vixos to mean "until victory is won," because they would have been familiar with the usual translation equiv-

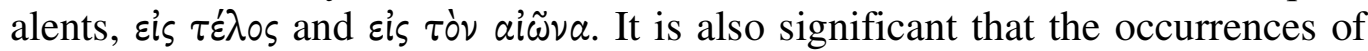
the noun נצח 1 Chr 29:11 and Lam 3:18 were translated with forms of vixos. Therefore, in Caird's opinion, the choice of vixos as translation equivalent for נצח must have been deliberate. Grindel approaches the issue from a different angle. He argues that the correspondence between נצח and vixos is a feature of what he calls the kaige "recension." According to Grindel, the kaige "recension" is

a recension of the Old Greek or Septuagint translation of the Old Testament which took place, around the turn of the era, in Palestine. Done in accordance with rabbinical hermeneutical principles then in force and in conformity with a Hebrew text then current in Palestine, it was this recension which Aquila in turn took up and developed in the second century A.D. A regular set of correspondents between the Hebrew and the Greek make it easily recognizable. ${ }^{47}$

Grindel's investigation reveals that the members of the kaige "recen-

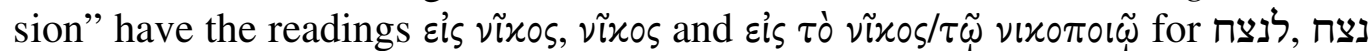
and למנצח in the MT. ${ }^{48}$ For למנצח and the version of Aquila reads שis vixos and $\tau \tilde{\omega} \nu$ v $x \circ \pi \circ i \tilde{\omega}{ }^{49}$ The evidence which he adduces in support of this argument is impressive. However, not all his conclusions can be accepted, since recent research demonstrates that a homogenous kaige recension did not exist. ${ }^{50}$ Scholars such as Greenspoon, Gentry and McLay point out that the kaige group does not only include revisions of Old Greek texts that aim to bring it closer to the proto-MT. There are translations that exhibit some of the kaige traits. The

46 Caird, "Towards a Lexicon," 136.

47 John A. Grindel, "Another Characteristic of the Kaige Recension: נצ/Vוx०s," $C B Q$ 31/4 (1969): 499. The traits of the kaige group that are most characteristic of these revisions and translations include: (1) the rendering of וגם/ by xai $\gamma \varepsilon$; (2) the consistent rendering of איש by ávท́p, even in cases where the former has the meaning

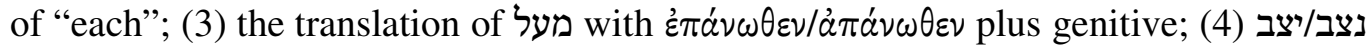

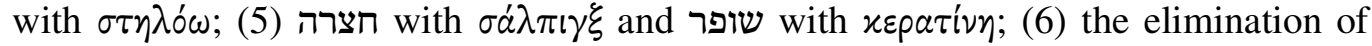

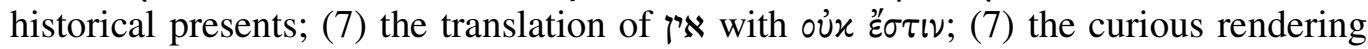

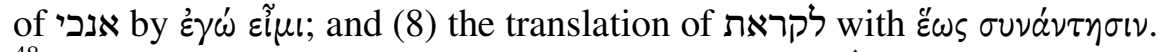

48 With regard to the two kaige translations of למנצת in the Psalm titles, see Grindel, "Kaige," 504-506.

49 Grindel, "Kaige," 512.

50 Cf. Leonard J. Greenspoon, "The Kaige Recension: The Life, Death, and Postmortem Existence of a Modern- and Ancient Phenomenon," in XII Congress of the International Organization for Septuagint and Cognate Studies, Leiden 2004 (ed. Melvin K. H. Peters; SBLSCS 54; Atlanta: Society of Biblical Literature, 2006), 5-16; and R. Timothy McLay, "Kaige and Septuagint Research," Textus 19 (1998): 127139. 
kaige group can, therefore, not be defined as a recension. Furthermore, these scholars indicate that the kaige group of translations and revisions are not uniform. Not all the characteristics that have been attributed to the kaige group are consistently shared by all its members. There are also important differences between the members that need to be taken into account. ${ }^{51}$ These criticisms levelled against the view that kaige is a uniform recension lead to the conclusion that it can only refer to a group of translations and revisions which share certain Greek translation equivalents for particular Hebrew words and phrases. The fact that the original Greek translation of Lamentations is a member of the kaige group means that the reading eis vixos in LXX Lam 5:20 cannot simply be explained as a by-product of recensional activity. It was the translator of LXX Lam who made the decision to translate לנצח with שis Vixxos and נצח in Lam 3:18 with vixos. However, if the crux of Grindel's argument is accepted, namely that the translation of נצח with vixos is a kaige feature, it would appear as though the Greek translator of Lamentations simply chose this group's default equivalent to render נצח in Lam 3:18 and 5:20. In the case of LXX Lam 5:20, this choice of translation equivalent creates a semantic tension between eis vixos and the context of the verse.

The argument that Eis vixos in LXX Lam 5:20 is an example of the translator's use of standard Greek translation equivalents for certain Hebrew words still leaves the reason why vixos was chosen to translate נצח unaccounted for, as well as the fact that this translation equivalent is also found in Old Greek texts that are not members of the kaige group. With regard to Eis vixos in the Old Greek texts of $2 \mathrm{Kgdms}$ 2:26, Jer 3:5, Amos 1:11 and 8:7 and vixy in $1 \mathrm{Chr}$ 29:11, some scholars ${ }^{52}$ argue convincingly that the translators rendered נצח after the sense which this root has in Aramaic. ${ }^{53}$ Such an Aramaising rendering was not necessarily due to a conscious exegetical decision. The translators'

51 Furthermore, the suggested links between the kaige traits and the Palestinian rabbinic exegesis are, at times, precarious. Cf. Leonard J. Greenspoon, "Recensions, Revision, Rabbinics: Dominique Barthélemy and Early Developments in the Greek Traditions," Textus 17 (1990): 153-167.

52 Cf. Emanuel Tov, The Text-Critical Use of the Septuagint in Biblical Research (2nd rev. \& enl. ed.; Jerusalem: Simor, 1997), 179; Peter Walters, The Text of the Septuagint: Its Corruptions and their Emendation (Cambridge: Cambridge University Press, 1973), 35; Samuel R. Driver, Notes on the Hebrew Text and the Topography of the Books of Samuel (2nd ed.; Oxford: Clarendon Press, 1913), 128.

53 Regarding Greek translations of Hebrew words according to their meanings in Aramaic, see Jan Joosten, "On Aramaising Renderings in the Septuagint," in Hamlet on a Hill: Semitic and Greek Studies Presented to Professor T. Muraoka on the Occasion of his Sixty-Fifth Birthday (ed. Martin F. J. Baasten and Wido van Peursen; OLA 118; Leuven: Peeters, 2003), 587-600. See also Jan Joosten, "The Septuagint as a Source of Information on Egyptian Aramaic in the Hellenistic Period," in Aramaic in its Historical and Linguistic Setting (ed. Holger Gzella and Margaretha L. Folmer; Wiesbaden: Harrassowitz Verlag, 2008), 93-105. 
knowledge of both Aramaic and $\mathrm{Hebrew}^{54}$ and the long history of contact between the two languages, which resulted in Aramaic influence on Hebrew (especially, but not exclusively, Late Biblical Hebrew, Qumran Hebrew and Mishnaic Hebrew), ${ }^{55}$ could explain why the translators, at times, inadvertently attribute Aramaic meanings to words in their Hebrew Vorlagen. According to Joosten,

The mind of the translators can never be known with certainty. Nevertheless, one might argue that the creation of Aramaising renderings in the Septuagint is due in greater measure to unconscious confusion than to philological exegesis. Certainly the factor of unconscious influence is much more important than has hitherto been admitted in scholarly literature. Even where the context is difficult, and the word at issue poorly attested, one should not automatically presume that recourse was taken to Aramaic in a conscious and deliberate way. ${ }^{56}$

Every Old Greek passage in which Vixos appears as a translation equivalent for נצח must therefore be studied in order to determine whether the Aramaic meaning of נצח makes sense in the context of the passage or not. Where it does not make sense, it is very probable that the translator was unconsciously influenced by the Aramaic meaning of נצח. In LXX Lam 5:20, عis vixxos is the original translation of לנצח and represents the Aramaic meaning of נצח. This meaning is not quite appropriate in the context of the verse. The translator's knowledge of Aramaic might therefore have had an unconscious effect on his understanding of נצח's meaning. If the rendering of נצח by Vixos proves to be a characteristic of the kaige group of translations and revisions, this would have facilitated the translator's choice of vixos as the translation equivalent of נצח in Lam 5:20. ${ }^{57}$

54 Joosten, "Aramaising Renderings," 599, argues that the translators of the Septuagint were trilingual: "Greek would have been their mother tongue, Hebrew the language of scripture and study, and Aramaic a language they used in certain undefined situations or localities."

55 Cf. Ian Young, Robert Rezetko and Martin Ehrensvärd, Linguistic Dating of Biblical Texts (vol. 1; London: Equinox, 2008), 208; Joosten, "Aramaising Renderings," 594.

56 Joosten, “Aramaising Renderings," 592.

57 The line of interpretation presented here to explicate the reading Eis Vix Lam 5:20 is incompatible with Kevin Youngblood's claim that the Greek translation of "betrays the more developed eschatology of Second Temple Judaism and expresses faith in the vindication of God's people at the end of time." See Kevin Youngblood, "The Character and Significance of LXX Lamentations," in Great Is Thy Faithfulness? Reading Lamentations as Sacred Scripture (ed. Robin A. Parry and Heath A. Thomas; Eugene: Pickwick, 2011), 68. Although Youngblood correctly treats LXX Lam as a theological and historical resource, the dearth of knowledge about 
Notwithstanding the conclusion that the prepositional phrase eis Vĩxos is ill-suited in the context of LXX Lam 5:20, the Greek wording of the rest of the verse follows the meaning of the Hebrew text. The deliberative questions in the Greek translation inquire about the reason why the Lord will forget the speakers and whether it is possible that he will abandon them for a long period of time. These questions, which have to do with the way in which the Lord will relate to the speakers in the future, form the basis for the imperatives in the next verse, which present the content of the speakers' hope regarding their future.

\section{$3 \quad$ Lamentations 5:21}

MT

השיבנו יהוה אליך ונשוב חדש ימינו כקדם

Turn us back to you, YHWH, so that we may return;

Renew our days as in ancient/former times.

\section{LXX}

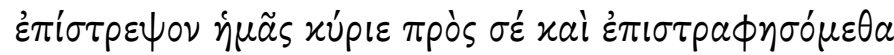

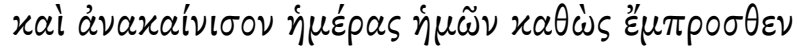

Turn us back to you, Lord, and we shall return;

Renew also our days like before.

In the MT, the speaking voice of Lam 5 articulates the content of the community's hope in v. 21. The community hopes that YHWH will re-establish the former (covenant) relationship between them and that he will bring back the community's good old days. These hopes are verbalised in the form of two imperatives addressed to YHWH (חדש and השיבנו) that are found in each of the verse's two cola. In the first colon, the hip 'il imperative השיבנון forms a verb sequence with ונשוב, which is vocalised as a qal cohortative in the MT. ${ }^{58}$ According to this sequence of verbs, the cohortative indicates the purpose of the imperative. ${ }^{59}$ The verbal root of both words is שוב. Holladay, who has made an exhaustive lexical study of שוב, argues that ונשוב in Lam 5:21 are

who the translator was, when, where and for whom he made the translation, as well as his reasons for engaging in the task of translation create difficulties for any attempt to use this translation unit as a source of information about Second Temple Judaism. Such information as is available on these matters can mostly be inferred from the original wording of the translation. These inferences depend, to some extent, on the explanations that text-critics provide to account for the cases where the wording of the original Greek translation deviates from the wordings of the extant Hebrew textual representatives.

58 The qere reading ונשובה also appears in a number of Masoretic manuscripts.

59 Cf. Christo H. J. van der Merwe, Jacobus A. Naudé and Jan H. Kroeze, A Biblical Hebrew Reference Grammar (Sheffield: T. \& T. Clark, 1999), 171. 
examples of the so-called "covenantal usage" of שוב. Whereas the central meaning of שוב involves the return of a mover to the initial point of departure, ${ }^{61}$ the covenantal usage of שוב expresses "a change of loyalty on the part of Israel or God, each for the other." to refer to the return to or re-establishment of a previous relationship and not to the establishment of a new one. ${ }^{63}$ If Holladay's arguments are accepted, the first colon of MT Lam 5:21 would entail that the community pleads with YHWH to accept them back as his covenant partner. The purpose of this acceptance would be that the community may return to their former covenant relationship השיבנו ... ונשוב ${ }^{\text {with YHWH. }}{ }^{64}$ The underlying assumption of the verb sequence in MT Lam 5:21a is that only YHWH can re-establish the relationship that the community enjoyed with him in the past. The people are incapable of restoring the relationship with YHWH, and therefore they hope that YHWH will be the one to do it. ${ }^{65}$

The second colon of MT Lam 5:21 parallels the first colon in that the community implores YHWH to act as he has done in the past. They call on YHWH to make their days new. ימינו can be understood as a metonym for what is happening to the community (or what happened to them in the very recent past). Thus, they plead with YHWH to transform their circumstances of suffering, which are recounted in vv. 2-18 and epitomised by the desolate Mount Zion. The prepositional phrase כקדם ("as in ancient/former times") is an adjunct that functions adverbially to modify the imperative the impression that, according to the speakers, the renewal they hope for would not be unparalleled, but has precedents in the olden days. Alternatively, כקדם can be interpreted as the norm for the renewal of the community's days. On this interpretation, the community requests that YHWH bring back the good old days of the community when they were YHWH's people and he was their God. ${ }^{67}$ This probably implies, as Gottwald argues, a plea for a "return of national freedom under king and priesthood with independence of movement, re-establishment

60 William L. Holladay, The Root šûbh in the Old Testament: With Particular Reference to its Usages in Covenantal Contexts (Leiden: Brill, 1958) 58, 79.

61 Holladay, šûbh, 53.

62 Holladay, šûbh, 116.

63 Holladay, šûbh, 120.

64 This line of interpretation of MT Lam 5:21a is not accepted by all scholars. Some see in a plea for a return from exile to Zion, while others interpret it in terms of a conversion. Cf., e.g., Delbert R. Hillers, Lamentations (2nd rev. ed.; AB 7; New York: Doubleday, 1992), 165.

65 Cf. Salters, Lamentations, 372; Johan Renkema, Lamentations (HCOT; Leuven: Peeters, 1998), 628; and Hans-Joachim Kraus, Klagelieder (Threni) (4th ed.; BKAT; Neukirchen-Vluyn: Neukirchen Verlag, 1983), 91.

66 Cf. $B D B: 869$.

67 Cf. Salters, Lamentations, 373. 
of civil order and the exercise of worship and festivity." ${ }^{\text {,6 }}$ In both interpretations, the speakers orientate their hope towards the past.

Like the MT, the Greek translation of v. 21 provides the content of the hope that finds expression in LXX Lam 5:19-22. The hope of the community whose voice is heard in these verses revolves around a return to the Lord and a renewal of their days.

The wording of the Greek translation adheres closely to the word order of the Hebrew text and every constituent part of the latter is represented by a

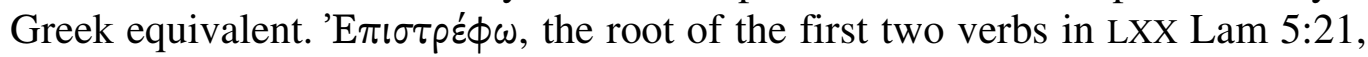
is the customary translation equivalent of forms of שוב in LXX Lam. The

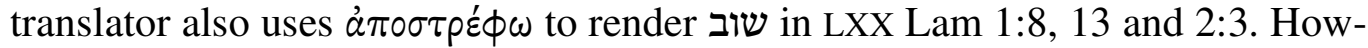
ever, in most of the occurrences of this Hebrew verbal root in Lamentations, the translator chooses to translate it with $\dot{\varepsilon} \pi \iota \tau \rho \varepsilon \dot{\varepsilon} \omega$ (cf. Lam 1:11, 16, 19; 2:8,

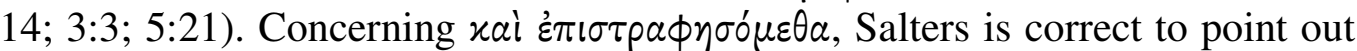
that the Hebrew Vorlage of this reading cannot be determined. ${ }^{69}$ Even though it is possible that the translator read the Hebrew verb as a weyiqtol and not as a cohortative, the function of the Hebrew verbal sequence is not captured in the Greek translation. Conversely, the translator rendered the prepositional phrase כקדם accurately by means of the adverbial phrase $x a \theta \dot{\omega} \varsigma$ है $\mu \pi \rho \circ \sigma \theta \varepsilon \nu . " E \mu \pi \rho \circ \sigma \theta \varepsilon \nu$ modifies ávaxaivıoov and clearly has a temporal, not a local, meaning. ${ }^{70}$ A cursory glance at the wording of LXX Lam 5:21 therefore leaves the impression of a literal translation that focuses on the meanings of individual words and merely employs routine equivalents. Such an impression is somewhat misleading on two accounts. First, the second xal in the Greek text is a plus compared to the wording of the MT. There is no reason to suspect an error in either the wording of the MT or the wording of the Hebrew Vorlage of the Greek translation. Consequently, the plus can be attributed to the translator's decision to join the two sentences of the verse by means of a coordinating conjunction. The relation between the sentences of this verse might therefore have been a matter of interest for the Greek translator. Secondly, a look at the content of the verses in the immediate context of LXX Lam 5:21 opens up the possibility that the choice of $\dot{\pi} \pi \sigma \tau \rho \varepsilon \dot{\phi} \omega$ to render the forms of שוב in this verse might have

68 Norman K. Gottwald, Studies in the Book of Lamentations (London: SCM Press, 1954), 110. Gottwald points out that for the Israelites "it was impossible to think of a bright future without the reconstruction of those ancient and venerated forms through which God made his will and goodness known."

69 Salters, Lamentations, 371.

70 Interestingly, James H. Moulton and George Milligan, Vocabulary of the New Testament (London: Hodder \& Stoughton, 1930; repr. Peabody: Hendrickson, 1997), 208 , note that $\varepsilon^{\prime} \mu \pi \rho \circ \sigma \theta \varepsilon \nu$ is commonly used in the Greek documentary papyri in a temporal sense. Cf. also the discussion of Raija Sollamo, Renderings of Hebrew Semiprepositions in the Septuagint (Helsinki: Suomalainen Tiedeakatemia, 1979), 321. 
been more considered than it might at first appear. This possibility merits closer scrutiny.

In Septuaginta Deutsch, Hirsch-Luipold and Maier translate $\dot{\pi} \pi \dot{\sigma} \sigma \rho \varepsilon \psi \circ \nu$

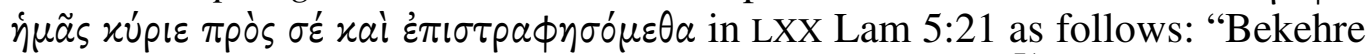
uns, Herr, zu dir, und wir wollen uns bekehren lassen."71 Assan-Dhôte also suggests that $\dot{\varepsilon} \pi \iota \tau \rho \dot{\varepsilon} \phi \omega$ evokes here the nuance of "le repentir", and draws attention to the Old Latin translation converte nos Deus ad te, et convertemur. ${ }^{73}$ In the passive voice, $\dot{\varepsilon} \pi$ $\sigma \tau \rho \varepsilon \dot{\varepsilon} \omega$ can indeed have the meaning "be converted." 74 However, this is not the sense communicated by $\varepsilon \pi i \sigma \tau \rho \varepsilon \psi \circ \nu$ and $\varepsilon \dot{\pi} \sigma \tau \rho \alpha ф \eta \sigma o ́ \mu \varepsilon \theta \alpha$ in LXX Lam 5:21, if conversion can be defined as the deliberate change from an earlier form of piety to another, different and new, form of conduct and/or set of beliefs. ${ }^{75}$ The community who is speaking in LXX Lam 5 pleads with the Lord to turn them back to him and to restore their former circumstances just as he has done before. The wording of LXX Lam 5:21 hints at the fact that the community wants to return to the relationship which it once

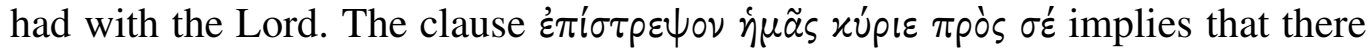
is a palpable divide between the Lord and the community, a divide which the community wants to cross. Yet, they can only do so if the Lord bridges the gap and causes them to come back to him. In the community's view, their desired return to the Lord depends on whether he will heed their request to take them back. The observations in LXX Lam 5:20 and 22 confirm that there is a rift between the community and the Lord and that the prerogative to repair the relationship rests with the Lord alone. In v. 20, the community asks whether the Lord will forever forget/neglect ( $\dot{\pi} \pi \lambda \alpha \nu \theta \alpha^{\prime} \nu \mu_{\mu}$ l) and abandon them/leave them behind ( $\varkappa \alpha \tau \alpha \lambda \varepsilon i \pi \omega)$. The implication is that the Lord has departed from them.

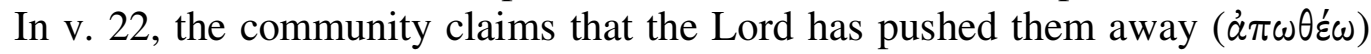
and that this is the cause for their need to return to him and to have their days renewed. The speakers' claim that the Lord left them and pushed them away implies that the Lord created the distance between himself and the community. The questions in v. 20 and statement in v. 22 envelop the community's pleas in v. 21 for a return to their previous relationship and for a restoration of, presumably, the times when they enjoyed the Lord's proximity. In view of this,

71 Hirsch-Luipold and Maier, "Threnoi/Die Klagelieder," 1358.

72 Assan-Dhôte and Moatti-Fine, Baruch, 284.

73 Cf. Pierre Sabatier, Bibliorum sacrorum latinae versiones antiquae seu Vetus Italica et caeterae quaecunque in codicibus manuscriptis et antiquorum libris reperiri potuerunt: quae cum Vulgata Latina, \& cum Textu Graeco comparantur (Vol. 2; Remis: Reginaldum Florentain, 1743), 733.

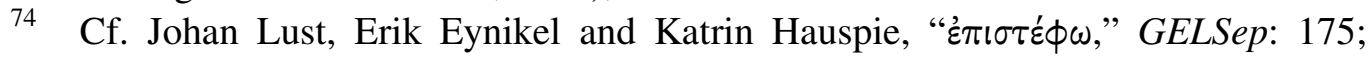

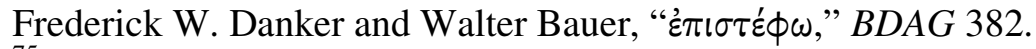

75 Cf. the discussion of conversion in antiquity by Arthur D. Nock, Conversion: The Old and the New in Religion from Alexander the Great to Augustine (Oxford: Clarendon Press, 1930). 
ध่ $\pi / \sigma \tau \rho \varepsilon ́ \phi \omega$, in its meaning "to turn/bring back," seems to be a well-chosen translation equivalent for שוב in the context of v. 21.

The hope for a future restoration expressed in the LXX version of the verse is, at least partly, predicated on the renewals that the Lord has, supposedly, brought about in the past ( $\kappa a \theta \dot{\omega} \varsigma \varepsilon^{\prime} \mu \pi \rho \circ \sigma \theta \varepsilon \nu$ ). Thus, the Greek wording of Lam 5:21 presents the speakers' hope as an expectation of a future possibility that is grounded in an experience of the past.

\section{$4 \quad$ Lamentations 5:22}

\section{MT}

כי אם מאס מאסתנו קצפת עלינו עד מאד

Even though/but instead/unless you have completely/truly rejected us, you are exceedingly angry with us.

\section{LXX}

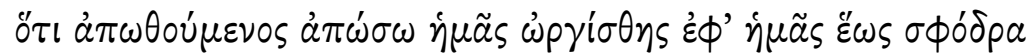

Because, by rejecting, you rejected us; you became exceedingly angry with us.

The poet returns to the theme of divine rejection in the final verse of Lam 5. The wording of this verse has stimulated much discussion among modern commentators. The combination of the words and אם at the beginning of the verse constitutes the crux interpretum and scholars are divided in their opinions regarding the correct way to understand these two words. There are a number of tenable interpretations of כי אם and the choice for any one of these possibilities depends on how scholars understand the verse in its literary context, especially in its relationship to v. $21 .^{76}$ The first option is to let כם and retain their separate meanings. כי would then function as a conjunction and would introduce a conditional clause. On this interpretation, the second colon of the verse, קצפת עלינו עד מאד, expresses the consequence of the condition. Ehrlich favours this understanding of כי מאדינר and translates the verse as follows: "Denn, wolltest du uns gänzlich verwerfen, du gingest in deinem Zorn gegen uns zu weit.",77 Linafelt also interprets כי אם along these lines, but he offers a novel translation of the verse: "For if truly you have rejected us, bitterly raged against us...",78

76 Some commentators render the bicolon as questions: "Or have you utterly rejected us? Are you exceedingly angry with us?" This is problematic, because nowhere else in the HB introduces a question.

77 Arnold B. Ehrlich, Randglossen zur hebräischen Bibel: Textkritisches, Sprachliches und Sachliches (vol. 7; Leipzig: J. C. Hinrichs, 1914), 54.

78 He explains: "I have chosen to translate the line as a conditional statement that is left trailing off, leaving a protasis without an apodosis, or an 'if' without a 'then.' The book is left opening out into the emptiness of God's nonresponse. By leaving a conditional statement dangling, the final verse leaves open the future of the ones lament- 
The second solution to the problem posed by the verse is to assign כי אם an adversative meaning: "but instead." Hillers ${ }^{79}$ adopts this interpretation of אם and mentions three other passages in the HB where it must also be understood in this way (Num 24:22; 1 Sam 21:5; 2 Sam 13:33). ${ }^{80}$ The adversative sense of כי אם in v. 22 also fulfils an important function in Williamson's argument regarding public and hidden transcripts in Lam $5 .^{81}$

ing. It is hardly a hopeful ending, for the missing but implied apodosis is surely negative, yet it does nevertheless defer that apodosis. And by arresting the moment from an 'if' to a 'then' the incomplete clause allows the reader, for a moment to imagine the possibility of a different 'then,' and therefore a different future." Tod Linafelt, Surviving Lamentations: Catastrophe, Lament, and Protest in the Afterlife of A Biblical Book (Chicago: Chicago University Press, 2000), 60-61. See also Tod Linafelt, "The Refusal of a Conclusion in the Book of Lamentations," JBL 120 (2001): 340343.

79 Hillers, Lamentations, 160-161.

80 Cf. also Dobbs-Allsopp, Lamentations, 148-149; Adele Berlin, Lamentations: A Commentary (OTL; Louisville: Westminster John Knox, 2002), 125; and Albrektson, Studies in the Text, 206.

81 Robert Williamson, "Lament and Acts of Resistance: Public and Hidden Transcripts in Lamentations 5," in Lamentations in Ancient and Contemporary Cultural Contexts (ed. Nancy C. Lee and Carleen Mandolfo; Atlanta: Society of Biblical Literature, 2008), 67-80. Williamson draws on the work of James C. Scott, who investigates the discourse between subordinate groups and their dominant authorities. Scott refers to the "polite patterns of speech designed to appeal to the selfinterest of the dominant" as the subordinate group's "public transcript" (Williamson, "Lament," 68). Scott shows that a second type of discourse, the so-called "hidden transcript," lies behind the "public transcript": "The 'hidden transcript' is normally employed when the subordinate is 'offstage' and out of earshot of the dominant ... The hidden transcript contains the subordinate's frustration and anger, which cannot be expressed publically for fear of reprisal" (Williamson, "Lament," 69). Williamson goes on to argue that the communal lament is an Israelite form of public transcript in which the vassal, Israel, can give voice to its complaints in a way that is acceptable to the covenantal suzerain, YHWH. He identifies Lam 5 as a communal lament in which the speakers accuse YHWH of inflicting great suffering on them and subjecting them to severe public humiliation. The communal voice in the lament "speaks as a punished and degraded subordinate addressing a dominant it perceives as angry and excessively violent" (Williamson, "Lament," 72). Williamson remarks that in this case one would expect to find a hidden transcript behind the public transcript of communal lament. In this regard, he highlights three ways in which Lam 5 departs from the normal form of the communal lament: First, the complaint section of the lament (vv. 2-18) is much longer than usual; secondly, the turn toward God only comprises one verse (v. 19), which is directly followed by another complaint in the next verse; and thirdly, there is no vow of praise after the petition in this lament. Verse 22 is, in Williamson's opinion, the pièce de résistance, because it contradicts the expected expressions of trust and praise by replacing them with the accusation that YHWH has completely rejected the speakers in his great anger. 
Although כי אם usually has a restrictive sense ("unless") after a negative clause, ${ }^{82}$ some scholars argue that כי אם in Lam 5:22 can be interpreted in this way. ${ }^{83}$ Berges, for example, defends this interpretation by claiming that the negation is implicit in v. $21 .^{84}$

Finally, Gordis puts forward another possible interpretation of כי אם in Lam 5:22. He argues that the verse is a subordinate clause that relates the circumstances surrounding the petition in the main clause found in v. 21.85 כי אם, which introduces the subordinate clause, has, in Gordis's opinion, a concessive meaning: "even though"/"although." He mentions four other passages in the HB where כי אם should be understood in this way: Jer 51:14, Isa 10:22, Amos 5:22 and Lam 3:32. Even though Gordis's interpretation of כי אם has found favour with some scholars, his rendering of the two perfect verbs מאספת and as as pluperfects has not. ${ }^{86}$

The function of the infinitive absolute construction in the first colon of the verse also merits a closer inspection. Recent studies of the infinitive absolute have shown that it typically features in modal contexts where the factual nature of events might be in dispute. ${ }^{87}$ In such cases, speakers can use the

82 For restrictive/exceptive clauses with כי אם after negative statements, see Paul Joüon and Takamitsu Muraoka, A Grammar of Biblical Hebrew (2 vols.; Rome: Pontifical Biblical Institute, 2005), 643; Bruce K. Waltke and Michael O'Connor, An Introduction to Biblical Hebrew Syntax (Winona Lake: Eisenbrauns, 1990), 671; and Wilhelm Gesenius, Gesenius' Hebrew Grammar (ed. Emil Kautsch; trans. Arthur Ernest Cowley; 2nd ed.; Oxford: Clarendon Press, 1910), 500.

83 Cf. Iain W. Provan, Lamentations (NCBC; Grand Rapids: Eerdmans, 1991), 133; Wilhelm Rudolph, Das Buch Ruth. Das Hohe Lied. Die Klagelieder (KAT; Gerd Mohn: Gütersloher Verlaghaus, 1962), 257-258; Ulrich Berges, Klagelieder (HTKAT; Freiburg: Herder, 2002), 272.

84 Berges, Klagelieder, 272

85 Robert Gordis, "The Conclusion of the Book of Lamentations (5:22)," JBL 93 (1974): 289-293. Cf. also Ignatius G. P. Gous, "Lamentations 5 and the Translation of Verse 22," OTE 3 (1990): 287-302.

86 Cf. Salters, Lamentations, 373-375; Robin A. Parry Lamentations (THOTC; Grand Rapids: Eerdmans, 2010), 154-157; Paul R. House, Lamentations (WBC; Nashville: Thomas Nelson Publishers, 2004), 470-472.

87 Cf. Christo H. J. van der Merwe, "The Infinitive Absolute Reconsidered: Review Article," JNSL 39/1 (2013): 61-84; Yoo-Ki Kim, The Function of the Tautological Infinitive in Classical Biblical Hebrew (HSS 60; Winona Lake: Eisenbrauns, 2009); and Scott N. Callaham, Modality and the Biblical Hebrew Infinitive Absolute (AKM 71; Wiesbaden: Harrassowitz Verlag, 2010). Kim provides synchronic and diachronic perspectives on the infinitive absolute construction and argues that its basic function is to allow a speaker to express commitment to the factuality of a proposition (Kim, Tautological Infinitive, 75). Callaham argues that in the majority of its appearances in the $\mathrm{HB}$, the infinitive absolute features in modal contexts. In these contexts, the infinitive absolute construction (which Callaham calls the paronomastic infinitive absolute) 
infinitive absolute to confirm their assumptions or convictions regarding the factuality of events. ${ }^{88}$ The infinitive absolute can also describe the mode of an action, especially the degree or intensity (e.g., the extreme, limited or continuous manner) of the action. ${ }^{89}$ This occurs mainly (but not exclusively) in nonmodal contexts where the factuality of events is not contested. Accordingly, van der Merwe points out that the information structure of the context in which the infinitive absolute appears (whether the factuality of an event is discourse active or not) has a key role to play in determining its function. ${ }^{90}$ With regard to מאס מאסתנו in Lam 5:22, the speakers' complaint in vv. 2-18, their questions in v. 20 concerning the duration of their abandonment by YHWH and their pleas for restoration in v. 21 indicate that the poet of Lam 5 presents the speakers' experience of divine rejection as a factual reality. The infinitive absolute either draws focus on the degree or intensity of the rejection expressed by the finite verb, or it helps to confirm the speakers' conviction of the factuality of this divine action. The choice between these possible interpretations of the infinitive absolute construction will, to some extent, be determined by the meaning one ascribes to כי אם. This, in turn, will have an impact on the perceived rhetorical force of the pleas in v. $21 .{ }^{91}$ If כי אם has a restrictive sense, it

focuses attention on the modality of the collocated cognate finite verb. Concerning the modal uses of the infinitives absolute, Callaham (Modality, 17-31) draws on the work of Frank Robert Palmer and distinguishes primarily between propositional and event modality. Propositional modality concerns the factuality of a proposition, while event modality refers to the conditioning factors that surround an event (Callaham, Modality, 22-31, 123).

88 Cf., e.g., Kim, Tautological Infinitive, 64-89.

89 Van der Merwe, "Infinitive Absolute," 78-79. Cf. also Callaham, Modality, 189208, who notes that infinitives absolute adverbially intensify the verbal idea in nonmodal contexts.

90 Van der Merwe, "Infinitive Absolute," 81, 82.

91 Callaham, Modality, 58, claims that the infinitive absolute construction in Lam 5:22 has an epistemic speculative modal sense. This means that a speaker "considers that a proposition may be true, though it is not necessarily true" (Callaham, Modality, 57). On this interpretation of the infinitive absolute construction, Lam 5:22 indicates that YHWH may have rejected his people, but the poet does not assert this directly. In view of the speculation concerning YHWH's rejection of his people, it is also not certain whether the pleas for restoration in v. 21 will be realised. It is true that the interpretation of v. 22 has a bearing on the matter of YHWH's possible reconciliation with the speakers in the future as it is articulated in the previous verse. In my opinion, however, Callaham's interpretation of the infinitive absolute construction in Lam 5:22 does not account for the fact that כי אם can be interpreted in various ways and that these different interpretation options impact on the rhetoric of the passage, including the meaning of the infinitive absolute. Furthermore, it does not reckon with the possibility that the rejection referred to in vv. 20 and 22 (as it is formulated in the MT) can be construed as an experienced reality for the speakers. The rejection might also be presented as a reality because divine abandonment is a theme that appears in other 
is possible that the pleas of v. 21 might still be realised, but it depends on the degree to which YHWH has rejected the community: "...unless you have completely rejected us." On this interpretation of the utterance, the infinitive absolute highlights the extent of the rejection. This would also be the case if כי אם is understood in an adversative sense. Such an interpretation of כי אם and the infinitive absolute entirely rules out the possibility of a restoration of the relationship between YHWH and the community: "but instead you have completely rejected us." In Gordis's interpretation of כי אם, it introduces a subordinate clause which indicates that the pleas of v. 21 are addressed to YHWH in spite of the fact that he has rejected the community. According to this concessive interpretation of כי אם, the infinitive absolute would confirm the factuality of the rejection: "...even though you have indeed/truly rejected us." A concessive understanding of כי אם is, however, also compatible with the view that the infinitive absolute in this verse marks the intensity of the action of the finite verb: "...even though you have completely rejected us." On this reading of the opening colon of Lam 5:22, the speakers have no illusions about the serious nature of the breach in their relationship with YHWH. In spite of their conviction that YHWH as completely rejected them, they nevertheless plead with him to restore them to himself. ${ }^{92}$ Their plea for restoration therefore has the character of "hope against hope."

The Old Greek text of Lam 5:22 presents a literal translation of the verse. The Greek wording imitates the word order of the Hebrew and apart from כי אם, all the constituent parts of the Hebrew words and clauses are represented by a Greek equivalent. The Hebrew infinitive absolute plus finite verb construction is rendered in Greek by a present participle followed by a finite

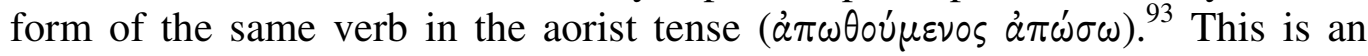

laments (e.g., Sumerian city laments) and the poet of Lam 5 might have wanted to incorporate this theme into the rhetoric of the communal lament he put into writing.

92 The interpretation of the infinitive absolute as an adverbial modifier that describes the intensive degree of the accompanying qatal verb contributes to the semantic parallelism between the two cola of the verse. Whereas the two verbal phrases מאסתנו and מצפת עלינו correspond with one another, the infinitive absolute construction in the first colon corresponds to the adverbial qualification עד מאד מin the second colon.

93 In view of the fact that the Greek language does not have an exact equivalent for the Hebrew infinitive absolute construction, Emanuel Tov, "Renderings of Combinations of the Infinitive Absolute and Finite Verbs in the Septuagint: Their Nature and Distribution," in The Greek and Hebrew Bible: Collected Essays on the Septuagint (Leiden: Brill, 1999), 247-256, shows that the translators of the Greek Jewish scriptures used different Greek constructions to translate it: (1) the combination of an infinitive and a finite verb, (2) a finite verb and adverb, (3) a finite verb together with a Greek noun (in the accusative or dative case), (4) the combination of a participle and a finite verb, (5) a finite verb and an adjective, and (6) a finite verb alone. The Greek translator of Lamentations usually rendered infinitive 
unidiomatic, even Hebraistic, use of the Greek participle. ${ }^{94}$ Nevertheless, it implies that the translator understood the infinitive absolute in his Hebrew Vorlage to have an adverbial function. ${ }^{95}$ In the case of LXX Lam 5:22, the

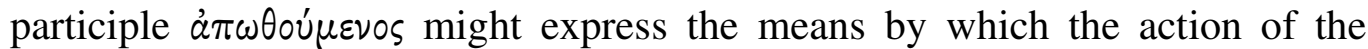
main verb $\dot{\alpha} \pi \dot{\omega} \sigma \omega$ is accomplished. ${ }^{96}$ The verb $\alpha \pi \omega \theta \varepsilon \dot{\varepsilon} \omega$ means "to push back/aside," but it also has the figurative sense "to reject" in its semantic field. $^{97}$ The Greek translator employed forms of this verb to render three Hebrew verbs in Lamentations: מאס (Lam 3:45; 5:22), גזר, (nip 'al) "to be cut off," that is, to be lost or destroyed (Lam 3:54) and "to reject" (Lam 2:7; $3: 17,31)$. According to Assan-Dhôte, these renderings imply that God's rejection of his people is a theme that is emphasised throughout the Greek translation of Lamentations. ${ }^{98}$

Another example of the literal nature of the verse's Greek translation is the rendering of עד מאד. The Greek translator represented both parts of this

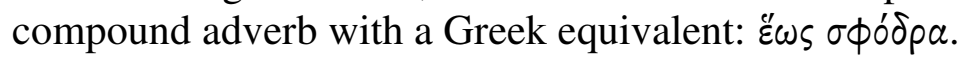

Turning to the Greek counterpart of כי אם in the MT, ö $\tau \iota$ appears to be a translation of כי alone. This might only be the result of the Greek translator's interpretation of the verse's difficult opening words and does not necessarily imply a variant Hebrew Vorlage. ${ }^{99}$ The translator also rendered the other appearance of כי אם in Lamentations (3:32) with ö $\tau$. In both verses, ö $\tau$ เ has a

absolute constructions by means of a participle and a (cognate) finite verb (Lam 1:2, 1:20, 3:52 and 5:22). However, in one instance (Lam 3:20), he translated the construction with only a finite verb.

94 Cf. Kim, Tautological Infinitive, 8-10, 85-87; Anneli Aejmelaeus, "Participium coniunctum as a Criterion of Translation Technique," in On the Trail of Septuagint Translators: Collected Essays (Kampen: Kok Pharos, 1993), 8-9; Raija Sollamo, "The LXX Renderings of the Infinitive Absolute Used with a Paronymous Finite Verb in the Pentateuch," in La Septuaginta en la Investigacion Contemporanea (V Congreso de la IOSCS) (ed. Natalio Fernández Marcos; Madrid: Instituto Arias Montano, 1985), 101-113; Henry St. J. Thackeray, A Grammar of the Old Testament in Greek according to the Septuagint (Cambridge: Cambridge University Press, 1909), 47-50; and Frederick C. Conybeare and St. George Stock, Grammar of Septuagint Greek (Boston: Ginn, 1905; repr., Peabody: Hendrickson, 1988), 74-75.

95 Cf. Raija Sollamo, "Why Translation Technique and Literalness Again? The Renderings of the Infinitive Absolute in the Septuagint of Jeremiah," in Congress Volume Helsinki 2010 (VTSup 148; ed. Martti Nissinen; Leiden: Brill, 2012), 6.

96 Sollamo, "LXX Renderings," 105, points out that the participial construction used to translate the infinitive absolute is "passable," albeit unidiomatic, Greek. These "paronomastic participles" in the LXX are, in her opinion, either modal or pleonastic.

97 Muraoka, "đ̊ $\pi \omega \theta \varepsilon \dot{\varepsilon} \omega$," GELS: 88; Lust, Eynikel and Hauspie, “ả $\pi \omega \theta \varepsilon \dot{\varepsilon} \omega$," GELSep:

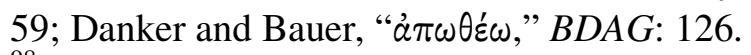

98 Assan-Dhôte and Moatti-Fine, Baruch, 176, 284.

99 Albrektson, Studies in the Text, 207. 
causal function. ${ }^{100}$ Nevertheless, Rudolph refers to six Hebrew manuscripts collated by Kenicott that contain the reading כי כי אם anstead of Lam 5:22. ${ }^{101}$ Furthermore, the Peshitta translation equivalent, $\mathrm{x}$, implies that the Syriac translator only rendered כי. It is, therefore, possible that the Old Greek and Peshitta translations were based on Hebrew Vorlagen that differed slightly from the wording of Codex Leningradensis. כי אם can be considered as the lectio difficilior and the minus of אם in some extant manuscripts (and probably the Hebrew Vorlagen of the Greek and Syriac translations) can be attributed to a scribal error. ${ }^{102}$

The causal sense of ö $\tau \iota$ means that v. 22 in the Old Greek text supplies the reason for the pleas in v. 21. Since the Lord rejected the speakers and was very angry with them, they cannot restore the relationship with God themselves and they cannot, on their own steam, return to the former times when they enjoyed the Lord's good graces. Therefore, in v. 21, they plead with the Lord to turn them back to him and to renew their days like before, that is, to bring them back into a happy relationship with him. In view of God's rejection and anger mentioned in v. 22, the speakers in the Greek translation seem to recognise that the restoration of their former relationship with the Lord is his prerogative, not theirs. In other words, the realisation of what they hope for is totally dependent on the Lord.

\section{CONCLUSION}

This study attempts to make a small contribution to a better understanding of LXX Lam as a witness to the content of Lam 5:19-22 by means of comparative analyses of the Greek and Hebrew wordings of these verses. The analyses focused on the Greek translation's presentation of the hope in Lam 5:19-22 and examined both the translation technique and the reasons for differences between the LXX and MT wordings of the four verses.

The analyses lead to the conclusion that LXX Lam 5:19-22 can be described, in general, as a quantitative, formal equivalent translation of a Hebrew text that was close to, but not identical to the consonantal base of the MT (as represented by Codex Leningradensis). At vv. 19 and 22 the differences between the LXX and the MT are, in all probability, the result of variant readings

100 Concerning the causal meaning of ö $\tau$, see Anneli Aejmelaeus, "O $\tau \iota$ causale in Septuagint Greek," in On the Trail of Septuagint Translators: Collected Essays (Kampen: Kok Pharos, 1993), 17-36.

101 Rudolph, Klagelieder, 258.

102 Rudolph, Klagelieder, 258, suggests that might be a secondary plus which can be explained as a dittograph of the first two letters of מאס, but Schäfer, "Lamentations," $136 *$, notes that אם could have been omitted by haplography or a phonological error. The presence of mem and 'aleph in the following words of the clause could have triggered the error. 
in the Vorlage of the Greek translation. The translator's knowledge of Aramaic might have determined the use of Eis vixos to render לנצח in v. 20. Since the translation of נצח with forms of Vixos also appears in other translation units, one cannot rule out the possibility that the translator of Lamentations was influenced by, what might have been, an established translational practice among certain scribes. The other differences between the Greek and Hebrew texts of

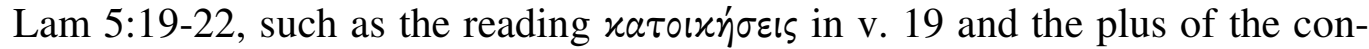
junction $x a l$ in v. 21, can be attributed to the translator.

Concerning the hope in LXX Lam 5:19-22, the conjunction $\delta \varepsilon$ in v. 19 explicitly states the contrast between the Lord, who dwells forever, and the symbol of his earthly abode, Mount Zion, which is destroyed and deserted (v. 18). The two clauses of this verse in the Greek translation portray God as a sovereign lord who remains unaffected by the disasters that have befallen the community and Zion. The speakers thereby confess that the Lord is in a position for them to pin their hopes on. In this regard, the community cherishes the hope that the Lord will in the future restore their former relationship. This hope is articulated in v. 21 by means of the two imperatives addressed to the Lord. The fact that the speakers actually voice their pleas implies that they consider the hoped for restoration and renewal to be realistic future possibilities. However, it also clear that the objects of their hope remain only possibilities and that it is far from certain that these possibilities will be realized. The hope of LXX Lam 5:21 takes the form of an uncertain attitude of expectation regarding a desired future. The uncertainty is evident from the questions and statements that flank the pleas for restoration and renewal. In v. 20, the speakers ask whether the Lord will forget them and forever abandon them, whereas in v. 22, they recognise that it is because the Lord rejected them and is angry with them that he created the distance between them. It is, therefore, solely his prerogative to restore their former relationship and thereby to fulfil the community's hope.

In conclusion, the quantitative, formal equivalent nature of the translation and the textual character of the Greek translation's Hebrew Vorlage cause the expression of hope in LXX Lam 5:19-22 to be similar, but not identical to its counterpart in the MT. This should be of interest to interpreters of Lamentations if they are willing to treat the Greek translation not merely as a witness to possible original Hebrew readings, but also as a legitimate witness to the content of this literary writing.

\section{BIBLIOGRAPHY}

Albrektson, Bertil. Studies in the Text and Theology of the Book of Lamentations: With a Critical Edition of the Peshitta Text. Lund: CWK Gleerup, 1963.

Aejmelaeus, Anneli. "Translation Technique and the Intention of the Translator." Pages 23-36 in VII Congress of the International Organization for Septuagint and Cognate Studies, Leuven 1989. Edited by Claude E. Cox. Society of 
148 Kotzé, "Comments on the Expression," OTE 28/1 (2015): 121-153

Biblical Literature: Septuagint and Cognate Studies 31. Atlanta: Scholars Press, 1991.

. "Participium coniunctum as a Criterion of Translation Technique." Pages 7-

16 in On the Trail of Septuagint Translators: Collected Essays. Edited by

Anneli Aejmelaeus. Kampen: Kok Pharos, 1993. . "O $\tau$ เ causale in Septuagint Greek." Pages 17-36 in On the Trail of

Septuagint Translators: Collected Essays. Edited by Anneli Aejmelaeus.

Kampen: Kok Pharos, 1993.

."What We Talk about When We Talk about Translation Technique." Pages

531-552 in X Congress of the International Organization for Septuagint and

Cognate Studies, Oslo, 1998. Edited by Bernard A. Taylor. Society of Biblical

Literature: Septuagint and Cognate Studies 51. Atlanta: Society of Biblical

Literature, 2001.

Assan-Dhôte, Isabelle and Jacqueline Moatti-Fine. Baruch, Lamentations, Lettre de Jérémie. La Bible d'Alexandrie 25.2. Paris: Cerf, 2005.

Barr, James. The Semantics of Biblical Language. Oxford: Oxford University Press, 1961.

. Biblical Words for Time. Rev. ed. Studies in Biblical Theology 33. London:

SCM Press, 1969.

Barthélemy, Dominique. Les Devanciers d'Aquila. Supplements to Vetus

Testamentum 10. Leiden: Brill, 1963.

Berges, Ulrich. Klagelieder. Herders Theologischer Kommentar zum Alten

Testament. Freiburg: Herder, 2002.

Berlin, Adele. Lamentations: A Commentary. Old Testament Library. Louisville:

Westminster John Knox Press, 2002.

Borowski, Oded. "Animals in the Literatures of Syria-Palestine.” Pages 289-306 in A

History of the Animal World in the Ancient Near East. Edited by Billie Jean

Collins. Handbuch der Orientalistik 64. Leiden: Brill, 2002.

Botterweck, G. Johannes, Helmer Ringgren, and Heinz-Josef Fabry, eds.

Theologisches Wörterbuch zum Alten Testament. Stuttgart: Kohlhammer, 1986.

Brown, Francis, Samuel R. Driver, and Charles A. Briggs. A Hebrew and English

Lexicon of the Old Testament. Oxford: Oxford University Press, 1906.

Caird, George B. "Towards a Lexicon of the Septuagint." Pages 110-152 in

Septuagint Lexicography. Edited by Robert A. Kraft. Septuagint and Cognate

Studies 1. Missoula: Scholars Press, 1975.

Callaham, Scott N. Modality and the Biblical Hebrew Infinitive Absolute.

Abhandlungen für die Kunde des Morgenlandes 71. Wiesbaden: Harrassowitz

Verlag, 2010.

Conybeare, Frederick C. and St. George Stock. Grammar of Septuagint Greek.

Boston: Ginn, 1905. Repr. Peabody: Hendrickson, 1988.

Danker, Frederick W. and Walter Bauer. A Greek-English Lexicon of the New

Testament and Other Early Christian Literature. 3rd ed. Chicago: University of Chicago Press, 2000.

Dobbs-Allsopp, Frederick W. Weep, O Daughter of Zion: A Study of the City-Lament Genre in the Hebrew Bible. Biblica et Orientalia 44. Rome: Pontifical Biblical Institute, 1993.

. Lamentations. Interpretation: A Bible Commentary for Teaching and

Preaching. Louisville: John Knox Press, 2002. 
Driver, Samuel R. Notes on the Hebrew Text and the Topography of the Books of Samuel. 2nd ed. Oxford: Clarendon Press, 1913.

Ego, Beate. "'Der Herr blickt herab von der Höhe seines Heiligtums': Zur Vorstellung von Gottes himmlischem Thronen in exilisch-nachexilischer Zeit." Zeitschrift für die Alttestamentliche Wissenschaft 110 (1998): 556-569.

Ehrlich, Arnold B. Randglossen zur hebräischen Bibel: Textkritisches, Sprachliches und Sachliches. Leipzig: J. C. Hinrichs, 1914.

Frevel, Christian. "Zerbrochene Zier: Tempel und Tempelzerstörung in den Klageliedern (Threni)." Pages 99-153 in Gottestadt und Gottesgarten: Zu Geschichte und Theologie des Jerusalemer Tempels. Edited by Othmar Keel and Erich Zenger. Quaestiones Disputatae 191. Freiburg: Herder, 2002.

Gentry, Peter J. "Lamentations." Pages 932-941 in A New English Translation of the Septuagint. Edited by Albert Pietersma and Benjamin G. Wright. Oxford: Oxford University Press, 2007.

Gesenius, Wilhelm. Gesenius' Hebrew Grammar. Edited by Emil Kautzsch. Translated by Arthur E. Cowley. 2nd ed. Oxford: Clarendon Press, 1910.

Gordis, Robert. "The Conclusion of the Book of Lamentations (5:22)." Journal of Biblical Literature 93 (1974): 289-293.

Gottwald, Norman K. Studies in the Book of Lamentations. Studies in Biblical Theology 14. London: SCM Press, 1954.

Gous, Ignatius G. P. "Lamentations 5 and the Translation of Verse 22." Old Testament Essays 3 (1990): 287-302.

Greenspoon, Leonard J. "Recensions, Revision, Rabbinics: Dominique Barthélemy and Early Developments in the Greek Traditions.” Textus 17 (1990): 153-167. . "The Kaige Recension: The Life, Death, and Postmortem Existence of a Modern- and Ancient Phenomenon." Pages 5-16 in XII Congress of the International Organization for Septuagint and Cognate Studies, Leiden 2004. Edited by Melvin K. H. Peters. Society of Biblical Literature: Septuagint and Cognate Studies 54. Atlanta: Society of Biblical Literature, 2006.

Grindel, John A. "Another Characteristic of the Kaige Recension: נצח/vixos." Catholic Biblical Quarterly 31/4 (1969): 499-513.

Hillers, Delbert R. Treaty-Curses and the Old Testament Prophets. Biblica et Orientalia 16. Rome: Pontifical Biblical Institute, 1964. . Lamentations. Anchor Bible. New York: Doubleday, 1992.

Hirsch-Luipold, Rainer and Christl M. Maier. “Threnoi/Die Klagelieder.” Pages 13491358 in Septuaginta Deutsch: Das griechische Alte Testament in deutscher Übersetzung. Edited by Wolfgang Kraus and Martin Karrer. Stuttgart: Deutsche Bibelgesellschaft, 2009. . “Threnoi/Threni Seu Lamentationes/Die Klagelieder.” Pages 2827-2841 in Psalmen bis Daniel. Volume 2 of Septuaginta Deutsch: Erläuterungen und Kommentare zum griechischen Alten Testament. Edited by Martin Karrer and Wolfgang Kraus. Stuttgart: Deutsche Bibelgesellschaft, 2011.

Holladay, William H. The Root šûbh in the Old Testament: With Particular Reference to its Usages in Covenantal Contexts. Leiden: Brill, 1958.

House, Paul R. Lamentations. Word Bibilical Commentary. Nashville: Thomas Nelson Publishers, 2004. 
Hurowitz, Victor A. "YHwH's Exalted House - Aspects of the Design and Symbolism of Solomon's Temple." Pages 63-110 in Temple and Worship in Biblical Israel. Edited by John Day. London: T. \& T. Clark, 2007.

Janowski, Bernd and Ute Neumann-Gorsolke. "Das Tier als Exponent dämonischer Mächte." Pages 278-282 in Gefährten und Feinde des Menschen: Das Tier in der Lebenswelt des alten Israel. Edited by Bernd Janowksi, Ute NeumannGorsolke and Uwe Gleßmer. Neukirchen-Vluyn: Neukirchener Verlag, 1993.

Jenni, Ernst. "Das Wort 'ōlām im Alten Testament." Zeitschrift für die Alttestamentliche Wissenschaft 64 (1952): 197-248.

Joosten, Jan. "On Aramaising Renderings in the Septuagint." Pages 587-600 in Hamlet on a Hill: Semitic and Greek Studies Presented to Professor T. Muraoka on the Occasion of his Sixty-Fifth Birthday. Edited by Martin F. J. Baasten and Wido van Peursen. Orientalia Lovaniensia Analecta 118. Leuven: Peeters, 2003. . "The Septuagint as a Source of Information on Egyptian Aramaic in the Hellenistic Period." Pages 93-105 in Aramaic in its Historical and Linguistic Setting. Edited by Holger Gzella and Margaretha L. Folmer. Wiesbaden: Harrassowitz Verlag, 2008.

Joüon, Paul and Takamitsu Muraoka. A Grammar of Biblical Hebrew. 2 Vols. Rome: Pontifical Biblical Institute, 2005.

Keel, Othmar. Die Welt der altorientalischen Bildsymbolik und das Alte Testament: Am Beispiel der Psalmen. 3rd ed. Zürich: Benziger Verlag / NeukirchenerVluyn: Neukirchener Verlag, 1980.

Kim, Yoo-Ki. The Function of the Tautological Infinitive in Classical Biblical Hebrew. Harvard Semitic Studies 60. Winona Lake: Eisenbrauns, 2009.

Knierim, Rolf P. "Hope in the Old Testament." Pages 244-268 in The Task of Old Testament Theology: Substance, Method and Cases. Edited by Rolf P. Knierim. Grand Rapids: Eerdmans, 1995.

Kraft, Robert A. "Eis Nikos = Permanently/Successfully: 1 Cor 15.54, Matt 12.20." Pages 153-156 in Septuagint Lexicography. Edited by Robert A. Kraft. Septuagint and Cognate Studies 1. Missoula: Scholars Press, 1975.

Krašovec, Jože. "The Source of Hope in the Book of Lamentations." Vetus Testamentum 42/2 (1992): 223-233.

Kraus, Hans-Joachim. Klagelieder (Threni). Biblischer Kommentar, Altes Testament. 4th ed. Neukirchen-Vluyn: Neukirchen Verlag, 1983.

Kruger, Paul A. "Disaster and the Topos of the World Upside Down: Selected Cases from the Ancient Near Eastern World." Pages 391-424 in Disaster and Relief Management: Katastrophen und ihre Bewältigung. Edited by Angelika Berlejung. Forschungen zum Alten Testament 81. Tübingen: Mohr Siebeck, 2012.

Labahn, Antje. "Wild Animals and Chasing Shadows: Animal Metaphors in Lamentations as Indicators for Individual Threat." Pages 67-97 in Metaphor in the Hebrew Bible. Edited by Pierre van Hecke. Leuven: Peeters, 2005.

Linafelt, Tod. Surviving Lamentations: Catastrophe, Lament, and Protest in the Afterlife of a Biblical Book. Chicago: Chicago University Press, 2000. . "The Refusal of a Conclusion in the Book of Lamentations." Journal of Biblical Literature 120 (2001): 340-343. 
Louw, Johannes P. and Eugene A. Nida, eds. Greek-English Lexicon of the New Testament Based on Semantic Domains. Cape Town: Bible Society of South Africa, 1993.

Lust, Johan, Erik Eynikel and Katrin Hauspie. A Greek-English Lexicon of the Septuagint. Stuttgart: Deutsche Bibelgesellschaft, 1992.

McLay, R. Timothy. “Kaige and Septuagint Research.” Textus 19 (1998): 127-139.

Moulton, James H. and George Milligan. Vocabulary of the New Testament. London: Hodder \& Stoughton, 1930. Repr. Peabody: Hendrickson, 1997.

Muraoka, Takamitsu. A Greek-English Lexicon of the Septuagint. Louvain: Peeters, 2009.

Nock, Arthur D. Conversion: The Old and the New in Religion from Alexander the Great to Augustine. Oxford: Clarendon Press, 1930.

Parry, Robin A. Lamentations. The Two Horizons Old Testament Commentary. Grand Rapids: Eerdmans, 2010.

Pietersma, Albert. "Kyrios or Tetragram: A Renewed Quest for the Original Septuagint." Pages 85-102 in De Septuaginta: Studies in Honour of John William Wevers on his Sixty-Fifth Birthday. Edited by Albert Pietersma and Claude Cox. Mississauga: Benben Publications, 1984.

Provan, Iain W. Lamentations. New Century Bible Commentary. Grand Rapids: Eerdmans, 1991.

Rahlfs, Alfred. Septuaginta: Id est Vetus Testamentum graece iuxta LXX interpretes: Editio altera quam recognovit et emendavit Robert Hanhart. Stuttgart: Deutsche Bibelgesellschaft, 2006.

Renkema, Johan. "Misschien is er Hoop...": De Theologische Vooronderstellingen van het Boek Klaagliederen. Kampen: Wever, 1983.

. Lamentations. Historical Commentary on the Old Testament. Leuven: Peeters, 1998.

Riede, Peter. “'Ich bin ein Bruder der Schakale' (Hi 30, 29): Tiere als Exponenten der gegenmenschlichen Welt in der Bildsprache der Hiobdialoge." Pages 120-132 in Im Spiegel der Tiere: Studien zum Verhältnis von Mensch und Tier im alten Israel. Edited by Peter Riede. Orbis Biblicus et Orientalis 187. Freiburg: Universitätsverlag / Göttingen: Vandenhoeck \& Ruprecht, 2002.

Robinson, Theodore H. “Threni.” Pages 1354-1367 in Biblia Hebraica Stuttgartensia. Edited by Karl Elliger and Wilhelm Rudolph. Stuttgart: Deutsche Bibelgesellschaft, 1977.

Rösel, Martin. "Theo-logie der griechischen Bibel: Zur Wiedergabe der Gottesaussagen im LXX -Pentateuch.” Vetus Testamentum 48/1 (1998): 49-62.

Rudolph, Wilhelm. "Der Text der Klagelieder." Zeitschrift für die Alttestamentliche Wissenschaft 56 (1938): 101-122.

. Das Buch Ruth. Das Hohe Lied. Die Klagelieder. Kommentar zum Alten Testament. Gerd Mohn: Gütersloher Verlaghaus, 1962.

Sabatier, Pierre. Bibliorum sacrorum latinae versiones antiquae seu Vetus Italica et caeterae quaecunque in codicibus manuscriptis et antiquorum libris reperiri potuerunt: quae cum Vulgata Latina, \& cum Textu Graeco comparantur.

Volume 2. Remis: Reginaldum Florentain, 1743.

Salters, Robin B. Lamentations. International Critical Commentary. London: T. \& T. Clark, 2010. 
152 Kotzé, “Comments on the Expression,” OTE 28/1 (2015): 121-153

Schäfer, Rolf. "Lamentations.” Pages 54-72 and 113*-136* in Biblia Hebraica quinta editione cum apparatu critico novis curis elaborato: General Introduction and Megilloth. Edited by Adrian Schenker, Yohanan A. P. Goldman, Arie Van Der Kooij, Gerard J. Norton, Stephen Pisano, Jan De Waard and Richard D. Weis. Stuttgart: Deutsche Bibel-gesellschaft, 2004.

Sollamo, Raija. Renderings of Hebrew Semiprepositions in the Septuagint. Helsinki: Suomalainen Tiedeakatemia, 1979.

"The LXX Renderings of the Infinitive Absolute Used with a Paronymous Finite Verb in the Pentateuch." Pages 101-113 in La Septuaginta en la Investigacion Contemporanea (V Congreso de la IOSCS). Edited by Natalio Fernández Marcos. Madrid: Instituto Arias Montano, 1985.

"Why Translation Technique and Literalness Again? The Renderings of the Infinitive Absolute in the Septuagint of Jeremiah." Pages 1-20 in Congress Volume Helsinki 2010. Supplements to Vetus Testamentum 148. Edited by Martti Nissinen. Leiden: Brill, 2012.

Thackeray, Henry St. J. A Grammar of the Old Testament in Greek according to the Septuagint. Cambridge: Cambridge University Press, 1909.

Thomas, Heath A. "II Will Hope in Him': Theology and Hope in Lamentations." Pages 203-221 in A God of Faithfulness: Essays in Honour of J. Gordon McConville on His 60th Birthday. Edited by Jamie A. Grant, Alison Lo, and Gordon Wenham. New York: Bloomsbury, 2011.

. Poetry and Theology in the Book of Lamentations: The Aesthetics of an Open Text. Sheffield: Sheffield Phoenix Press, 2013.

Tov, Emanuel. The Text-Critical Use of the Septuagint in Biblical Research. 2nd rev. and enl. ed. Jerusalem: Simor, 1997.

. "Renderings of Combinations of the Infinitive Absolute and Finite Verbs in the Septuagint: Their Nature and Distribution." Pages 247-256 in The Greek and Hebrew Bible: Collected Essays on the Septuagint. Edited by Emanuel Tov. Leiden: Brill, 1999.

Ueberschaer, Frank. "Die Septuaginta der Klagelieder: Überlegungen zu Entstehung und Textgeschichte." Pages 98-111 in Die Septuaginta: Entstehung, Sprache, Geschichte. Edited by Siegfried Kreuzer, Martin Meiser and Marcus Sigismund. Wissenschaftliche Untersuchungen zum Neuen Testament 286. Tübingen: Mohr Siebeck, 2012.

Van der Merwe, Christo H. J. "The Infinitive Absolute Reconsidered: Review Article." Journal of Northwest Semitic Languages 39/1 (2013): 61-84.

Van der Merwe, Christo H. J., Jacobus A. Naudé and Jan H. Kroeze. A Biblical Hebrew Reference Grammar. Sheffield: T. \& T. Clark, 1999.

Walters, Peter. The Text of the Septuagint: Its Corruptions and their Emendation. Cambridge: Cambridge University Press, 1973.

Waltke, Bruce K. and Michael O'Connor. An Introduction to Biblical Hebrew Syntax. Winona Lake: Eisenbrauns, 1990.

Weber, Robert. Biblia Sacra iuxta Vulgatam Versionem: Editionem quintam emendatam retractatam praeparavit Roger Gryson. Stuttgart: Deutsche Bibelgesellschaft, 2007.

Westermann, Claus. "Das Hoffen im Alten Testament: Eine Begriffsuntersuchung." Pages 219-265 in Forschung am alten Testament: Gesammelte Studien. Edited by Claus Westermann. München: Chr. Kaiser Verlag, 1964. 
Kotzé, "Comments on the Expression," OTE 28/1 (2015): 121-153

Williamson, Robert. "Lament and Acts of Resistance: Public and Hidden Transcripts in Lamentations 5." Pages 67-80 in Lamentations in Ancient and Contemporary Cultural Contexts. Edited by Nancy C. Lee and Carleen Mandolfo. Atlanta: Society of Biblical Literature, 2008.

Young, Ian, Robert Rezetko and Martin Ehrensvärd. Linguistic Dating of Biblical Texts. Volume 1. London: Equinox, 2008.

Youngblood, Kevin J. "The Character and Significance of LXX Lamentations." Pages 64-69 in Great Is Thy Faithfulness? Reading Lamentations as Sacred Scripture. Edited by Robin A. Parry and Heath A. Thomas. Eugene: Pickwick, 2011.

Ziegler, Joseph. Septuaginta: Vetus Testamentum Graecum Auctoritate Academiae Scientiarum Gottingensis editum XV: Jeremias, Baruch, Threni, Epistula Jeremiae. 3rd ed. Göttingen: Vandenhoeck \& Ruprecht, 2006.

Zimmerli, Walther. Man and his Hope in the Old Testament. London: SCM Press, 1971.

Dr. Gideon R. Kotzé, Department of Ancient Studies, Stellenbosch University, Private Bag X1 Matieland 7602.Email: grk@sun.ac.za 